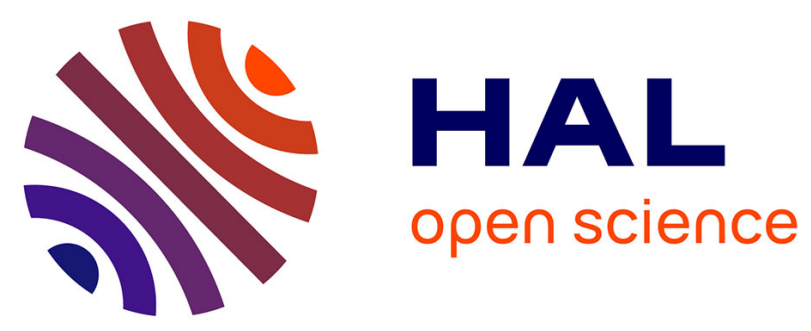

\title{
Co-variations of climate and silicate weathering in the Nile Basin during the Late Pleistocene
}

Luc Bastian, Carlo Mologni, Nathalie Vigier, Germain Bayon, Henry Lamb, Delphine Bosch, Marie-Emmanuelle Kerros, Christophe Colin, Marie Revel

\section{- To cite this version:}

Luc Bastian, Carlo Mologni, Nathalie Vigier, Germain Bayon, Henry Lamb, et al.. Co-variations of climate and silicate weathering in the Nile Basin during the Late Pleistocene. Quaternary Science Reviews, 2021, 264, pp.107012. 10.1016/j.quascirev.2021.107012 . hal-03405906

\section{HAL Id: hal-03405906 https://hal.science/hal-03405906}

Submitted on 27 Oct 2021

HAL is a multi-disciplinary open access archive for the deposit and dissemination of scientific research documents, whether they are published or not. The documents may come from teaching and research institutions in France or abroad, or from public or private research centers.
L'archive ouverte pluridisciplinaire HAL, est destinée au dépôt et à la diffusion de documents scientifiques de niveau recherche, publiés ou non, émanant des établissements d'enseignement et de recherche français ou étrangers, des laboratoires publics ou privés. 


\section{Co-variations of climate and silicate weathering} in the Nile Basin during the Late Pleistocene

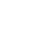

Luc Bastian ${ }^{1,2^{*}}$ \& Carlo Mologni ${ }^{1,3^{*} \dagger}$, Nathalie Vigier $^{2}$, Germain Bayon $^{4}$, Henry Lamb $^{5,6}$ Delphine Bosch ${ }^{7}$, Marie-Emmanuelle Kerros ${ }^{2}$, Christophe Colin $^{8}$, Marie Revel $^{1}$

(1)

$$
*^{c o}-1^{\text {st }} \text { authors }
$$

†corresponding author: mologni@geoazur.unice.fr

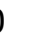

${ }^{1}$ Université de la Cote d'Azur, CNRS, OCA, IRD, Geoazur, 250 rue Albert Einstein, 06500 Valbonne, France

${ }^{2}$ Laboratoire d'Océanographie de Villefranche sur Mer (LOV, IMEV), CNRS, Sorbonne Université, 181 chemin du Lazaret, 06320, Villefranche sur Mer, France

${ }^{3}$ Université Côte d'Azur, Centre National de la Recherche Scientifique (CNRS), Cultures et Environnements. Préhistoire, Antiquité, Moyen Age (CEPAM) - UMR 7264, 24 av. des Diables Bleus 06300 Nice, France

${ }^{4}$ IFREMER, Unité de Recherche Géosciences Marines, 29280 Plouzané, France

${ }^{5}$ Department of Geography and Earth Sciences, Aberystwyth University, Aberystwyth SY23 $3 \mathrm{DB}, \mathrm{UK}$

${ }^{6}$ Botany Department, School of Natural Sciences, Trinity College, Dublin 2, Ireland

7 Géosciences Montpellier, UMR-CNRS 5243, Université de Montpellier , 34095 Montpellier, France

${ }^{8}$ Laboratoire GEOsciences Paris-Sud (GEOPS), UMR 8148, CNRS-Université de Paris-Sud, Université Paris-Saclay, Bâtiment 504, 91405 Orsay Cedex, France. 


\section{Abstract}

We have investigated provenance and weathering proxies of the clay-size sediment exported from the Nile River basin over the last 110,000 years. Using neodymium isotope composition of sediments from both the Nile Deep Sea-Fan and Lake Tana, we show that the Nile River branches draining the Ethiopian Highlands have remained the main contributors of clays to the Nile delta during the Late Quaternary. We demonstrate that fluctuations of clay-size particle contribution to the Nile Delta are mainly driven by orbital precession cycle, which controls summer insolation and consequently the African monsoon intensity changes. Our results indicate that - over the last 110,000 years - the proportion of clays coming from Ethiopian Traps fluctuates accordingly to the intensity of the last 5 precession cycles (MIS 5 to MIS 1). However, there is a threshold effect in the transport efficiency during the lowest insolation minima (arid periods), in particular during the MIS3. Several arid events corresponding to the Heinrich Stadial periods are associated with small or negligible clay source changes while chemical weathering proxies, such as $\delta^{7} \mathrm{Li}, \mathrm{Mg} / \mathrm{Ti}$ and $\mathrm{K} / \mathrm{Ti}$, vary significantly. This suggests a straightforward control of weathering by hydro-climate changes over centennial to millennial timescales. Our data also suggests a significant but more progressive influence of the temperature decrease between 110kyr and 20kyr. Taken altogether, the observed tight coupling between past climate variations and silicate weathering proxies leads us to conclude that precipitation changes in northeast Africa can impact soil development over a few hundred years only, while the influence of temperature appears more gradual. 


\section{Introduction}

Monsoons are the dominant seasonal mode of climate variability in the tropics, acting as important conveyors of atmospheric moisture and energy at the global scale (Mohtadi et al., 2016). In north-East Africa, the onset of Late Quaternary humid periods has been attributed to the northward migration of the rain belt associated with the Inter Tropical Convergence Zone (ITCZ) in relation with precession-driven insolation changes as well as the Congo Air Boundary (CAB; Demenocal et al., 2000; Gasse, 2000; Rossignol-Strick et al., 1982; Skonieczny et al., 2019, Tierney et al., 2010; Junginger et al., 2014). The last period of more intense rainfall compared to present, the so-called African Humid Period (AHP), occurred between 14 and $\sim 6$ kyrs cal. BP (e.g. Costa et al., 2014; Demenocal et al., 2000; Shanahan et al., 2015). These past humid periods were characterized by enhanced freshwater discharge and sediment export from the large African river systems to surrounding ocean margins (Blanchet et al., 2021; Mologni et al., 2020; Skonieczny et al., 2015). A number of recent studies conducted at a high temporal resolution (10-1000 years) in lake and deltaic sedimentary records across northern Africa suggested that gradual long-term monsoon oscillations had been often punctuated by millennial-scale episodes of hyperaridity (Bastian et al., 2017; Berke et al., 2012; Blanchet et al., 2020; Castañeda et al., 2016; Collins et al., 2013; Costa et al., 2014; Foerster et al., 2012; Liu et al., 2017; Tierney et al., 2013, 2011b, 2011a, 2008; Verschuren and Russell, 2009), as exemplified by significant increase in aeolian dust deposition in sediment records from African margins (Bouimetarhan et al., 2012; Collins et al., 2017, 2013; Heinrich et al., 2021; McGee et al., 2013; Tierney et al., 2017). These hyperarid episodes occurred contemporaneously with North Hemisphere cooling events recorded in Greenland ice cores (i.e. Greenland stadials; Dansgaard et al., 1993) and in North Atlantic sediment cores (Heinrich Stadials; Bond et al., 1993; Heinrich, 1988). Up to now, over the tropics, these events were mainly described through the use of organic biomarkers 
and bulk sediment geochemical tracers $\left(\delta \mathrm{D}_{\mathrm{wax}}\right.$, Ti/Ca ratio; Castañeda et al., 2016; Collins et al., 2017; Tierney et al., 2008; Tierney and DeMenocal, 2013). There is still debate about the exact mechanisms that would explain these short-term hydroclimate changes (orbital forcing and/or internal hemispheric versus nonlinear biogeophysical feedbacks processes; e.g. Collins et al., 2017, 2011).

Sediment deposition in deltas is usually dominated by the export of terrigenous material delivered from flooded rivers, highly sensitive to changes in precipitation rates and land cover in corresponding drainage basins (Macklin et al., 2012). The sediment records preserved at the Nile Deep-Sea Fan (NDSF) provide suitable archives for reconstructing past climate variations at a high temporal resolution (100 to 1000 years) in north-East Africa (AlmogiLabin et al., 2009; Bastian et al., 2017; Blanchet et al., 2013; Costa et al., 2014; Hamann et al., 2009; Hennekam et al., 2015; Mologni et al., 2020; Revel et al., 2015; Weldeab et al., 2014). Currently, about $95 \%$ of the terrigenous material deposited at the Nile deep-sea fan is derived from the Ethiopian Highlands (Garzanti et al., 2015; Padoan et al., 2011). A close link between precipitation and physical erosion in the Nile River basin has already been demonstrated for the Late Pleistocene period (e.g. Blanchet et al., 2014). Past humid periods were systematically accompanied by accelerated deposition of iron/smectite-rich sediments, reflecting enhanced physical erosion and transport processes from the Ethiopian Highlands (Blanchet et al., 2014; Krom et al., 2002, 1999; Langgut et al., 2011; Revel et al., 2015, 2014, 2010, Ehrmann et al., 2016).

In contrast, only a few studies have investigated past relationships between climate and silicate weathering on continents over the Quaternary period (Yang et al. 2020; Bastian et al., 2017; Bayon et al., 2012; Beaulieu et al., 2012; Clift et al., 2020, 2014; Dosseto et al., 2015; Limmer et al., 2012; Pogge von Strandmann et al., 2017). To date, there is no consensus on both the magnitude and the timing of chemical weathering response to rapid climate changes. 
During the last two decades, lithium isotopes (conventionally expressed as $\delta^{7} \mathrm{Li}$ ) have been explored as tracers of silicate weathering in both modern and ancient environments (Bastian et al., 2017; Dellinger et al., 2014, 2015, 2017; Huh et al., 1998; Philip A.E. Pogge von Strandmann et al., 2017; Pogge von Strandmann et al., 2010, 2020; Vigier et al., 2009). During weathering, mass-dependent isotope fractionation results in significant enrichment of the lighter lithium isotope $\left({ }^{6} \mathrm{Li}\right)$ into secondary mineral phases such as clays (Dupuis et al., 2017; Li and West, 2014; Pistiner and Henderson, 2003; Vigier et al., 2008; Wimpenny et al., 2010; Hindshaw et al., 2019). As reported or modeled in Bastian et al. (2017), Bouchez et al. (2013), Pogge von Strandmann et al. (2017, 2010), Misra and Froelich (2012), water or clay $\delta^{7} \mathrm{Li}$ values primarily reflect the degree of 'incongruency' of the continental weathering process, which is a function of the dissolution vs neoformation rate. Indeed, the proportion of - isotopically fractionated - Li incorporated into neoformed secondary phases, compared to the one released more congruently to waters during rock dissolution or mineral leaching, represents the most important control of $\mathrm{Li}$ isotope signatures in soils and rivers. When, at the basin scale, the denudation flux compensates the soil production rate, physical and chemical weathering processes are considered at steady-state and the 'incongruency ratio' is then directly related to the chemical weathering intensity (W/D, ratio of silicate chemical weathering over total denudation, as defined by Bouchez et al. [2013], Caves Rugenstein et al. [2019] and Dellinger et al. [2017]). Exception is made for basin with particular high W/D ratios, because dissolution is so intensive that secondary minerals also release to draining waters their isotopically light Li (leading to a "bell shape" trend of $\delta^{7} \mathrm{Li}$ as a function of W/D, see Dellinger et al., [2015] ).

The aim of our study is to better understand the impact of monsoon-rainfall changes on both erosion and weathering processes in the Nile Basin over the last 110 kyrs. Recently, Bastian et al. (2017) reported $\delta^{7} \mathrm{Li}$ measurements for a total of 55 clay-size sediment fractions extracted 
from core MS27PT from the NDSF. The obtained $\delta^{7} \mathrm{Li}$ data ranged between $4 \%$ and $-1.2 \%$

displaying systematic co-variations with proxies for hydroclimate variability over the last 32,000 years. Additional data are now needed to investigate whether this relationship held true over longer timescales. To this end, we have conducted a source-to-sink approach, which aimed at comparing sediment records from both the NDSF and the Lake Tana, located at the source of the Blue Nile River in the Ethiopian Highlands. Our approach combines the use of geochemical and isotopic tracers of sediment provenance ( $\mathrm{Nd}$ isotopes) and silicate weathering (major elements; Li isotopes). By focusing on the finest - clay rich- size fraction of the sediment $(<2 \mu \mathrm{m})$ we minimize potential complexities related to granulometric processes and mineral sorting occurring during sediment transport and deposition, as described in Bastian et al. $(2019,2017)$ for the Nile Basin. Additionally, our source-to-sink approach allows us to discuss the role of continental geomorphic processes on the terrigenous delivery to the Nile basin. Finally, this study includes the investigation at relatively high temporal resolution of several hyper-arid millennial-scale episodes (i.e. Heinrich Stadials).

\section{Regional setting and samples}

\subsection{Geological and hydrology setting of the Nile River Basin}

The Nile River Basin (about $3.3 \times 10^{6} \mathrm{~km}^{2}$ ) extends across more than 30 degrees of latitude (from $4^{\circ} \mathrm{S}$ to $30^{\circ} \mathrm{N}$, Fig. 1). It is composed of two major sub-drainage basins characterized by different lithologies, but overall dominated by silicate rocks (Ghilardi and Boraik, 2011). The Ethiopian Highlands, corresponding to the Ethiopian Traps (age of $\sim 30 \mathrm{Ma}$ ), is composed of Cenozoic basaltic rocks. The Sobat, the Blue Nile and the Atbara rivers originate from the Ethiopian Traps sources (Garzanti et al., 2015). The Central African Craton (age > $3 \mathrm{Ga}$ ) is composed of Precambrian metamorphic rocks drained by the Bahr el Jebel River (Garzanti et 
al., 2015), which is joined by the Sobat River to form the White Nile (Williams et al., 2015). Over the hydrological year, the Nile River displays a unimodal discharge patterns characterized by intense floods during the summer, essentially caused by the northward migration of the ITCZ, and associated monsoonal precipitation across the Ethiopian Highlands (Garzanti et al., 2015). The Bahr el Jebel/White Nile is originated from the equatorial uplands Uganda, Rwanda and Burundi, and in particular from the outflow of Lake Victoria and Lake Albert. The contribution of the Bahr el Jebel/White Nile remains more or less constant throughout the year, due to a more uniform rainfall pattern in the Equatorial region with 1-2 $\mathrm{m}$ of rainfall distributed in two rainy seasons (Garzanti et al., 2015; Nicholson, 2000).

Thus, the precipitation regime along the Nile catchment is mainly caused by the West African monsoon, modulated by the Indian Summer Monsoon (ISM) dynamics. Over the Ethiopian Highlands, precipitation is fed by moisture originating from three sources: the West African Monsoon (WAM), the Indian Ocean and the Mediterranean Sea, Arabian Peninsula and the Red Sea northern regions (Viste and Sorteberg, 2013). A range of 69-95\% and 5-24\% of the total precipitation are currently derived from the Gulf of Guinea and Indian Ocean, respectively (Costa et al., 2014; Verschuren et al., 2009). Runoff from the Ethiopian Traps (where $1500 \mathrm{~m}$ to $3000 \mathrm{~m}$ a.s.l. elevation concentrates most precipitation) greatly contributes to the lower Nile discharge and to a majority of its transported sediment (Lamb et al., 2007; Williams et al., 2006).

\subsection{Geochemical characterization of detrital sediments from the Nile River Basin}

The NDSF has built up continuously since the Oligocene through sedimentary inputs from the Nile River basin (Ducassou et al., 2009; Faccenna et al., 2019; Mascle, 2014; Migeon et 
al., 2010; Revel et al., 2015, 2014, 2010). For the last 110,000 years, the most active part of the fan has been the so-called Rosetta branch (Ducassou et al., 2009, 2008). Sedimentation rates at the NDSF have varied drastically from $\approx 400 \mathrm{~cm} / \mathrm{kyr}$ during humid periods such as AHP, to much lower accumulation rates $(\approx 1-10 \mathrm{~cm} / \mathrm{kyr})$ during arid periods (Ducassou et al., 2008; Langgut et al., 2011; Revel et al., 2010). This reduction of particulate fluxes is in line with the drying up of large lakes such as Lake Victoria, Albert, Tana situated in the Nile basin system (Gasse, 2000; Lamb et al., 2007; Talbot and Lærdal, 2000; Williams et al., 2006). The provenance of the sediment exported to the NDSF has been inferred from the Nd and $\mathrm{Sr}$ radiogenic isotope compositions of mud and sand fractions from sediments in transit along all major Nile branches (see map in Fig. 1; Garzanti et al., 2015; Padoan et al., 2011; Talbot and Brendeland, 2001; Woodward et al., 2015). Sediment Nd isotopic compositions (expressed from herein using the epsilon notation $\varepsilon \mathrm{Nd}$ ) are not affected much by weathering processes and hence faithfully reflects geographical provenance and crustal age of the source rocks (Bayon et al., 2015). The Nile basin is well suited to this isotopic tracer because of the contrasting $\varepsilon \mathrm{Nd}$ signatures characterized by the Cenozoic Ethiopian traps $(\varepsilon \mathrm{Nd} \approx 0$; Fig. 1) and the Precambrian Central Africa Craton $(\varepsilon N d \approx-30$, Garzanti et al., 2015). The Bahr el Jebel and Victoria-Albert Nile-derived fluvial muds are characterized by $\varepsilon \mathrm{Nd}(0)=-$ 25 and range from -29 to -36 , respectively (Padoan et al., 2011), whereas the White Nile mud $\varepsilon N d$ is around -10 , resulting from the mixture of basaltic (Ethiopian Traps) and metamorphic (Precambrian Craton) rocks. The present-day White Nile contributes to about 2 million tons of sediment particles to the main Nile at Khartoum, in contrast to the 41 and 14 million tones provided by the Blue Nile and Atbara rivers, respectively, before they were dammed (Williams et al., 2015). Thus, sediment budgets calculated by integrating isotopic data on muds and sands are consistent with dominant contribution from the Blue Nile and Atbara to total main Nile load, whereas the Bahr el Jebel/White Nile 
sediment loads contribution to the main Nile are less important (Garzanti et al., 2015; Padoan et al., 2011). The Sahara Desert, in particular the Libyan desert, represents another source of particles to the Nile Delta with aeolian dust inputs estimated at 20 to $40 \mathrm{~g} / \mathrm{m}^{2} / \mathrm{yr}$ (Grousset et al., 1988; Krom et al., 1999). The Saharan dust contribution (Saharan Metacraton sources characterized by $\varepsilon N d$ from -15 to -10; Abdelsalam et al., 2002; Grousset et al., 1988) depends on the aridity of the region and the wind strength. Also, the ArabianNubian Shields (ANS, Johnson et al., 2011) located along the Red Sea margin can be a minor source of particle, with $\varepsilon N d$ from -2.5 to -0.5 (Palchan et al., 2013). Thus, $\mathrm{Nd}$ isotopes have shown to be a powerful tool to investigate how sediment sources have changed in the past, in particular during the Late Quaternary (Bastian et al., 2017; Blanchet et al., 2015, 2021; Castañeda et al., 2009; Revel et al., 2015; Weldeab et al., 2003). At the scale of the Holocene and the last deglaciation, the highest $\varepsilon N d$ values recorded during the AHP, from $\sim 14$ to $\sim 8 \mathrm{ka} \mathrm{BP}$, indicate larger proportions of particles derived from the Ethiopian Traps (Bastian et al., 2017; Blanchet et al., 2014; Revel et al., 2015). Indeed, the radiogenic Nd isotopic signatures $(\varepsilon \mathrm{Nd} \approx-2)$ are closer to values observed in the Ethiopian Traps $(\varepsilon N d 0$ to 7). In contrast, during more arid periods, sediment deposited at the NDSF are characterized by lower $\varepsilon N d$ values (-8 to -12), indicating reduced sediment inputs from Ethiopian Traps, together with higher relative contributions from the other sediment sources. Previous studies have argued very low sediment contributions from the White Nile at present (about $3 \pm 2 \%$ of the total Nile sediment discharge; Garzanti et al., 2015). This is because most of the coarse grained sediment transported by the White Nile is trapped within the Sudd marshes in South Sudan (Fielding et al., 2017; Garzanti et al., 2015). However, it was not always the case. Indeed, during arid times, reduced Ugandan lakes overflow into Bahr el Jebel/White Nile, induces the Sudd swamps drying out, favouring thus the sediment delivery at the beginning of the following humid period (Williams, 2019). Additionally, water inputs of White Nile 
may have substantially changed through the time producing marked flooding events (Talbot and Lærdal, 2000; Williams, 2019; Williams et al., 2006, 2010). Thus, as proposed by Blanchet et al. (2013) using granulometric measurements, the Bahr el Jebel/White Nile may have represented, during the Late Pleistocene, a non-negligible source of sediments to the Nile River.

\subsection{Marine sediment core MS27PT from the Nile deep-sea fan}

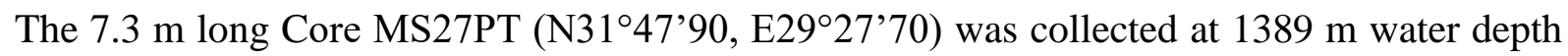
in the NDSF during the Mediflux MIMES cruise (2004), at around 90km from the Nile Rosetta River mouth. Its age model is based on 29 AMS ${ }^{14} \mathrm{C}$ dates first published in (Bastian et al., 2017; Revel et al., 2015, 2010) and on $\delta^{18}$ O stratigraphy (Revel et al., 2015, 2010; see Fig. S1 and Table S1). Core MS27PT lies directly under the influence of the Nile freshwater input and provides a continuous record of sediment discharge from the Nile River basin for the last 110 kyr (Mologni et al., 2020; Revel et al., 2015, 2014, 2010). This is well illustrated by high-resolution XRF core scanner $\log (\mathrm{Ti} / \mathrm{Ca}$ ) ratios (Fig. 2 and S1; Bahr et al., 2015; Liu et al., 2017; Revel et al., 2010), which reflect variable relative proportions of terrestrial versus marine inputs. Periods of low monsoon intensity were associated with deposition of lightcolored sediments dominated by biogenic carbonate shells (Fig. S1), while high monsoon periods usually correspond to darker -Fe-Ti rich - sediments derived from the Nile floods and also from a good preservation of organic matter within Sapropel layers (De Lange et al., 2008; Rohling, 1994; Rohling et al., 2015). In core MS27PT, Sapropels S4, S3 and S1 are visible and associated with high Sulphur concentrations and low foraminifera $\delta^{18} \mathrm{O}$ (Revel et al., 2010), which are contemporaneous with massive freshwater discharge from the Nile River. Clay fractions are continuously dominated by smectite (65 to $98 \%$ ), with illite, chlorite and kaolinite in smaller proportions (Revel et al., 2015, 2010; Table S2). 


\subsection{Lake sediment core 03TL3 from Lake Tana (Ethiopian Highlands)}

252

253

254

255

256

257

258

259

260

261

262

263

264

265

266

267

268

269

270

271

We have also analyzed $\varepsilon N d$ for the clay-size fractions extracted from core 03TL3, collected in 2003 in the central part of Lake Tana (13.8 m water depth; Lamb et al., 2007). Core 03TL3 covers the last $16 \mathrm{kyr}$ period. Lake Tana $\left(21^{\circ} \mathrm{N}, 37.25^{\circ} \mathrm{E}, 1830 \mathrm{~m}\right.$ a.s.l.; Fig. 1) is the largest lake in Ethiopia and represents, with the tributary downstream, the major source of water to the Blue Nile River. The age model of this core is based on $17 \mathrm{AMS}{ }^{14} \mathrm{C}$ dates published by Marshall et al. (2011). This sedimentary record first provides evidence for geochemical and mineralogical variations related to past changes in the monsoon activity (Costa et al., 2014; Lamb et al., 2007; Marshall et al., 2011). For instance, Costa et al. (2014) showed that $\delta D_{\text {wax }}$ (i.e. a proxy for past humidity) decreased during the African Humid Period, which was interpreted as reflecting higher rainfall contributions from the Atlantic Ocean at that time.

\section{Methods}

\subsection{Sampling, sediment treatment and clay extraction}

Each sample corresponds to a $1 \mathrm{~cm}$ cut section along studied sediment cores. Considering variations in sedimentation rates along sediment cores, this $1 \mathrm{~cm}$ cut corresponds to a time interval ranging from 10-70 years and 400-1000 years for humid and arid periods, respectively.

The sampling for the clay-sized fraction analyses of the $\mathrm{Nd} / \mathrm{Li}$ isotopes and $\mathrm{K} / \mathrm{Ti}$ and $\mathrm{Mg} / \mathrm{Ti}$ ratios is about $2 \mathrm{~cm}$ for the last 31,000 years (i.e. a temporal resolution of about 1000 years). For the last glacial period (75 to $25 \mathrm{kyr}$ ) the sampling is based on $\mathrm{K} / \mathrm{Al}$ ratio variations (see 
272 Fig S1) which indicates an increase in this ratio consistent with the timing of the Heinrich events recorded in North Atlantic (Snoeckx et al., 1999).

Bulk samples (about $0.5 \mathrm{~g}$ ) were first sieved at $63 \mu \mathrm{m}$ and dried at $65{ }^{\circ} \mathrm{C}$. Mineralogical composition of some fine-grained $<63 \mu \mathrm{m}$ sediment samples was determined by XRD Bruker D5000 at the University of Strasbourg (LHYGES). Before separation of the clay fraction from the $<63 \mu \mathrm{m}$ fraction, the sample was treated for carbonate removal using $1 \mathrm{~N} \mathrm{HCl}$ for $30 \mathrm{~min}$ in an ultrasonic bath. Clays $(<2 \mu \mathrm{m})$ were extracted from the carbonate-free detritus by physical decantation in $50 \mathrm{ml}$ of ultra-pure water mixed with $60 \mu \mathrm{l}$ of sodium hexametaphosphate solution $(100 \mathrm{mg} / \mathrm{l})$.

The clay minerals were identified by X-ray diffraction (XRD) using a PANalytical diffractometer at the GEOPS laboratory (Université Paris-Saclay, France) on oriented mounts. Briefly, deflocculation was accomplished by successive washing with distilled water after removing carbonate and organic matter by treating with acetic acid and hydrogen peroxide, respectively. Particles smaller than $2 \mu \mathrm{m}$ were separated by sedimentation and centrifugation. Three XRD runs were performed, following air-drying, ethylene-glycol solvation for 24 hours, and heating at $490^{\circ} \mathrm{C}$ for 2 hours. The clay minerals were identified according to the position of the (001) series of basal reflections on the three XRD diagrams. Mixed layers composed mainly of smectite-illite (15-17 $\AA$ ) were included in the "smectite" category. Semiquantitative estimates of peak areas of the basal reflections for the main clay mineral groups of smectite (15-17 $\AA$ ), illite (10 $)$ ), and kaolinite/chlorite $(7 \AA)$ were performed on the glycolated curve using the MacDiff software. The relative proportions of kaolinite and chlorite were determined based on the ratio from the 3.57/3.54 $\AA$ peak areas. The replicate analyses of a few selected samples gave a precision of $\pm 2 \%$. Based on this XRD method, the semi-quantitative evaluation of each clay mineral had an accuracy of $\sim 4 \%$. 
After drying, clays were crushed in an agate mortar and about $10 \mathrm{mg}$ of this powder was digested using a concentrated $\mathrm{HF} / \mathrm{HNO}_{3} / \mathrm{HCl}$ mixture. The solution was evaporated at low temperature and the residue was completely dissolved in $1 \mathrm{~N} \mathrm{HCl}$ prior to $\mathrm{Li}$ separation solid/liquid chromatography columns (Vigier et al., 2009).

\subsection{Measurement of major and trace element concentrations}

Major (K, Ca, Mg, Mn, Fe, Al ,Ti) and a few trace (Sr, Ba) elements were analyzed by ICPAES at the LOV. Accuracy was assessed using the certified reference material BEN and water standard TM 28.4. The $2 \sigma$ errors on concentrations range between $1.6 \%$ and $3.5 \%$ for major and trace elements (more details in Bastian et al., 2017).

\subsection{Lithium isotope analyses}

For chemical Li purification in the LOV clean lab, a solution containing $\sim 60 \mathrm{ng}$ of lithium was introduced on a cationic resin column (AG50X12) and Li was eluted using titrated ultrapure 1.0 N HCl (Vigier et al., 2008). This separation was performed twice to ensure perfect $\mathrm{Li}-\mathrm{Na}$ separation. $\mathrm{LiCl}$ solution was then evaporated to dryness and re-dissolved in $0.05 \mathrm{~N} \mathrm{HNO}_{3}$ for isotope analyses. Lithium isotope analyses were performed at the Ecole Normale Supérieure de Lyon (CNRS-INSU National Facilities) using a Neptune Plus (Thermo-Fisher) multi-collector inductively coupled plasma spectrometer (MC-ICP-MS) along with a sample-standard bracketing technique. A combination of Jet and X cones were used, as well as an Aridus II desolvating system, resulting in a sensitivity of 1 Volt ${ }^{7} \mathrm{Li} / \mathrm{ppb}$ (Balter and Vigier, 2014) Li (Balter and Vigier, 2014). Before analyses, Li fractions were diluted to match $5 \mathrm{ppb} \mathrm{Li}$. Total procedural blanks were negligible $(<10 \mathrm{pg} \mathrm{Li})$, representing $\sim 0.02 \%$ maximum of the total $\mathrm{Li}$ fraction for each sample. The accuracy of isotopic 
measurements was assessed several times during each measurement session using reference Li7-N solution (Carignan et al., 2007) and other reference materials (BE-N basaltic rock powder and seawater). Without separation chemistry, mean $\delta^{7} \mathrm{Li}$ values of $30.2 \pm 0.4 \%$ ( $2 \mathrm{SD}$, $\mathrm{n}=32$ ) were obtained for Li7-N, which compares well with published and nominal values (Carignan et al., 2007). After chemical purification, the mean values for $\delta^{7} \mathrm{Li}$ were $30.3 \pm 0.4$ (2SD, $\mathrm{n}=22), 5.45 \pm 0.2(2 \mathrm{SD}, \mathrm{n}=3)$ and $31.1 \pm 0.3 \%$ ( $2 \mathrm{SD}, \mathrm{n}=6)$ for Li7-N, BE-N and seawater, respectively, which also compare well with published values (Millot et al., 2004). To verify the homogeneity of the clay fraction and the reproducibility of clay separation, various aliquots of 5 different clay separations were also analyzed, resulting in a reproducibility of 0.37\% (2SD; $\mathrm{n}=14)$ as previously reported in (Bastian et al., 2018, 2017).

\subsection{Neodymium isotope analyses}

The Nile clay $\mathrm{Nd}$ isotopic compositions were measured at the Pôle Spectrométrie Océan (Brest, France). Neodymium was purified using conventional ion chromatography (Bayon et al., 2012). Nd isotopic compositions were determined using sample-standard bracketing, by analysing JNdi-1 standard solutions every two samples. Mass bias corrections were made using the exponential law considering ${ }^{146} \mathrm{Nd} /{ }^{144} \mathrm{Nd}=0.7219$. Mass-bias corrected values for ${ }^{143} \mathrm{Nd} /{ }^{144} \mathrm{Nd}$ were normalized to a JNdi-1 value of ${ }^{143} \mathrm{Nd} /{ }^{144} \mathrm{Nd}=0.512115$ (Tanaka et al., 2000). Repeated analyses of bracketed JNdi-1 standard solutions during the course of this study yielded ${ }^{143} \mathrm{Nd} /{ }^{144} \mathrm{Nd}$ of $0.512117 \pm 0.000012$ ( $2 \mathrm{SD}, \mathrm{n}=16$ ), corresponding to an external reproducibility of $\sim \pm 0.23 \varepsilon(2 \mathrm{SD})$.

Tana Lake clays have been processed at Geosciences Montpellier laboratory (University of Montpellier). The chemical separation of Nd includes a first step of separation using AG50WX-8 cation exchange resin to collect rare earth elements (REE), followed by a second step to 
purify Nd using HDEHP conditioned Teflon columns. Nd isotopes were measured using a Thermo-Fischer Neptune Plus MC-ICP-MS from the AETE-ISO geochemistry platform (OSU OREME). ${ }^{143} \mathrm{Nd} /{ }^{144} \mathrm{Nd}$ ratios were corrected from internal mass bias using an exponential law and a value of 0.7219 for the ${ }^{146} \mathrm{Nd} /{ }^{144} \mathrm{Nd}$ ratio. The external mass bias was corrected using standard bracketing method with two different standards (JMC321 and AMES-Rennes). During the course of the study JMC-321 and AMES-Rennes (Chauvel and Blichert-toft, 2001) standards yielded respectively an average of $0.511115 \pm 7(2 \sigma, n=8)$ and $0.512959 \pm 6(2 \sigma, \mathrm{n}=8)$ for the ${ }^{143} \mathrm{Nd} /{ }^{144} \mathrm{Nd}$ ratio. $\mathrm{Nd}$ procedural blank was $22 p g$. For all samples, epsilon $\mathrm{Nd}$ values $\left(\varepsilon_{\mathrm{Nd}}\right)$ were calculated using ${ }^{143} \mathrm{Nd} /{ }^{144} \mathrm{Nd}=0.512638$ (Bouvier et al., 2008).

\section{Results}

\subsection{Core MS27PT}

All geochemical data for core MS27PT clay fractions are presented in Tables 1 and S2. The $\mathrm{Nd}$ isotopic composition of clay-size fractions (clay $\varepsilon \mathrm{Nd}$ ) varies from -7.69 to -0.98 with a value of that falls down systematically to $\sim-7.5$ during low insolation periods. Under high insolation, clay $\varepsilon N d$ increases up to -4 (Fig. 2). The downcore evolution of $\varepsilon N d$ is in phase with $\log (\mathrm{Ti} / \mathrm{Ca})$ (Fig. 2) as well as with sedimentation rates (see Fig.S1). This documents higher detrital sediment inputs from Ethiopian Traps during the last five high insolation periods. Clay $\mathrm{Mg} / \mathrm{Ti}$ and $\mathrm{K} / \mathrm{Ti}$ ratios also oscillate between arid and humid periods (from $\approx 3.5$ to 2.5 and from $2.5-3$ to 1.5 respectively), with the highest values being systematically associated to the lowest insolation. Overall, during the last 110,000 years, geochemical tracers follow the insolation trend, hence variations in monsoon intensity in northern Africa (Singarayer and Burrough, 2015; Tjallingii et al., 2008). 
Over the last 110,000 years, clay $\delta^{7} \mathrm{Li}$ values range between $1 \%$ and $4 \%$, which is the same range of values already established for the last $35 \mathrm{kyr}$ from the same core (Bastian et al., 2017; Fig. 2). However, between $110 \mathrm{kyr}$ and $35 \mathrm{kyr}$, clay $\delta^{7} \mathrm{Li}$ do not show the same systematics with insolation as since $35 \mathrm{kyr}$ (Bastian et al., 2017). The centennial to decennial high resolution $\mathrm{Ti} / \mathrm{Ca}$ ratio (measured on the bulk sediment every mm by XRF core scanner) highlight lower values during the Younger Dryas (YD), during the five arid (low insolation) periods, as well as during several short-time excursions (Fig. 2). Indeed, from 70 to $10 \mathrm{kyr}$, clay $\delta^{7} \mathrm{Li}$ display specific short-term increases (pointed as arrows in Fig. 2), which are unrelated in terms of duration and intensity to the insolation curve. Some of these rapid excursions co-vary with elemental ratios, but some do not. An additional feature of the clay $\delta^{7} \mathrm{Li}$ record in core MS27PT is the progressive decrease of the $\delta^{7} \mathrm{Li}$ minima between 110 and 25 kyr BP (dotted line in Fig. 2).

\subsection{Core 03TL3 Lake Tana}

All data for core 03TL3 from the Lake Tana are displayed in Table 2.The $\varepsilon N d$ compositions of all clay-size fractions yields a mean value of 2.0 \pm 0.5 (2SD, n=13; Fig. 3), consistent with the $\varepsilon N d$ value determined for Blue Nile river sediments by Garzanti et al., $(2015)(\varepsilon N d=1.8$, Fig. 1). $\delta^{7} \mathrm{Li}$ values of clay-sized fractions from core $03 \mathrm{TL} 3$ range from $0.8 \%$ to $2.9 \%$ over the last $16 \mathrm{kyr} \mathrm{BP}$, with a mean value of $1.7 \%$. These values are comparable, within errors, to the ones obtained in core MS27PT clays for the same period (Fig. 3).

\section{Discussion}

As described in the Result section, the MS27PT sediments located in NDSF first show that various geochemical proxies evolve in phase with changes in the monsoonal system, which 
are primarily controlled by precession-forced insolation variations. During the last $110 \mathrm{kyrs,}$ each low insolation period (to a lesser degree for the one at $45 \mathrm{kyrs} \mathrm{BP}$ ), is characterized by a decrease in the clay $\varepsilon \mathrm{Nd}$ values, and by an increase in clay $\mathrm{Mg} / \mathrm{Ti}$ and $\mathrm{K} / \mathrm{Ti}$ ratios (Fig. 2).

In addition, geochemical analyses highlight numerous short-term excursions, in particular for $\mathrm{Li}$ isotopes, $\mathrm{K} / \mathrm{Ti}$ and $\mathrm{Mg} / \mathrm{Ti}$ ratios. Some of them - but not all - are accompanied by $\varepsilon \mathrm{Nd}$ drops, similar to those as during periods of low insolation, but less intensive in magnitude. These short excursions are in line with the timing of Heinrich Stadials, as determined in Greenland ice core (NGrip, Andersen et al., 2004) and in North Atlantic sediments (Collins et al., 2013; Hemming, 2004; see section 5.3.).

\subsection{Impact of insolation change on physical erosion and sediment transport}

\subsubsection{Provenance of clay fractions exported to the Nile deep-sea fan}

For the Nile River and other large river basins, regional paleoclimatic reconstructions are generally based on the application of geochemical proxies to the bulk detrital fraction, without particular grain-size separation (Costa et al., 2014; Lamb et al., 2018; Marshall et al., 2011; Revel et al., 2015, 2010; Tierney et al., 2011b). While clay mineralogy has been used for decades in paleoclimatic studies, the geochemistry of the finest clay-size sediment fractions $(<2 \mu \mathrm{m})$ has been largely unexplored, apart from a few paleoenvironmental studies (Bastian et al., 2017; Bayon et al., 2012; Blanchet et al., 2015; Chen et al., 2017; Clift et al., 2014; Dosseto et al., 2015). As shown in Fig. 4a for the last $110 \mathrm{kyrs,}$ in core MS27PT, the Nd isotopic compositions of clay-size fractions are systematically more radiogenic (and vary less) than $\varepsilon N d$ values of the corresponding silt-size fractions. This suggests a dominant basaltic source for the clays, which are mostly issued from the Ethiopian Traps region, in contrast to the silts that may derive from different provenance regions. 
For the last 16 kyrs, a "source-to-sink" approach could be developed by comparing the clay

417

418

419

420

421

422

423

424

425

426

427

428

429

430 signals extracted from both the NDSF and the Lake Tana sediment records; this latter being located $\sim 3500 \mathrm{~km}$ upstream, in the Ethiopian Highlands. During this period, clay $\varepsilon N d$ values for sediment deposited in the Lake Tana remained constantly high, with a mean value of $2 \pm$ 0.25 (Fig. 3a; in agreement with the regional lithology), similar - within uncertainties - to the $\varepsilon N d$ value of $1.8 \pm 0.8$ measured in mud sediments carried at present by the Blue Nile River (Garzanti et al., 2015; Fig. 3a). Most likely, the clays transported by the Blue Nile, Atbara and Sobat rivers were formed locally within the soils developed above basaltic and rhyolitic Ethiopian Traps sequences. Differently from Blue Nile/Atbara rivers, the Ethiopian Traps radiogenic signature of the Sobat River would be originated from the Lake Turkana overflow events (towards the lower White Nile basin) occurring during humid periods (Johnson and Malala, 2009).

During the last $16 \mathrm{kyrs}$, clay $\delta^{7} \mathrm{Li}$ values are similar in the MS27PT core and in the Lake Tana core (Fig. 3b). This first confirms that most of the clay material exported to the NDSF at this period came from the Ethiopian Highlands, and that measured $\delta^{7} \mathrm{Li}$ compositions can actually reflect weathering conditions, without being significantly affected by sediment transport nor by any post-depositional effect related to diagenetic processes.

In contrast, clays from MS27PT sediment exhibit lower $\varepsilon N d$ values (mean value of -4.36 , $\mathrm{n}=94$ ) than for the Lake Tana (mean value of 2, n =13 for the last $14 \mathrm{kyr}$; Fig. 3a and 4a) over the last 110.000 years. However, Blue Nile sources remains relatively stable and high compared to the Bahr el Jebel/White Nile sources (Fig. 4a). In fact, a small increase in the contribution of clay-size material from the Central African Craton ( $\varepsilon N d \sim-30)$ has a significant impact on $\varepsilon \mathrm{Nd}$ values. This effect likely explains the bias observed between clay $\varepsilon N d$ values from core MS27PT and from Lake Tana sediments. 
The smectite abundance measured in the clay fractions over the last 110 kyrs also remains high (> 65\%), suggesting that $\varepsilon N d$ signature and smectite clay contribution are both sensitive to clay sources (Figs. 2 and 4). Thus, our "source-to-sink" approach demonstrates that clays from the Ethiopian Traps (Blue Nile/Atbara and Sobat rivers) represent the dominant sediment source to the NDSF sediment for the last 110 kyrs (Fig. 4). In contrast, clays derived from Saharan dust (Saharan Metacraton) and from the Bahr el Jebel/White Nile (Cetral African Craton) or from the Red Sea Hills (Arabian Nubian Shield) contribute comparatively in much lower proportion. Importantly, $\varepsilon N d$ show that the proportion of Ethiopian Trapsoriginated clays remains high ( $\varepsilon N d$ values oscillate between -8 and -2 ) even during arid periods, suggesting persistent soil and clay formation over the Ethiopian Highlands.

\subsubsection{Threshold effects on sediment transport during the Younger Dryas}

During arid periods the increased difference in $\varepsilon N d$ values between clays and silts from the NSDF (Fig. 4a) suggest that both particle types come from different and lithologically contrasted regions. Thus, the variable $\varepsilon N d$ difference between clays and silts could be explained by different size-dependent transport processes, as well as by possible threshold effects on the transport of coarser particles. This aspect is well illustrated when considering the Younger Dryas period (YD; Fig. 5). In northern Africa, the Younger Dryas is generally associated with a relatively arid period from $\sim 13$ and $\sim 12 \mathrm{kyr} B P$, resulting from a weakening of monsoon intensity (Garcin et al., 2007) and from the fall of lakes level (Roberts et al., 1993; Stager and Johnson, 2008). In core MS27PT, this period is highlighted by progressively decreasing sediment $\mathrm{Ti} / \mathrm{Ca}$ ratios, consistent with lower terrigenous inputs (Fig. 5, Revel et al., 2015, 2014, 2010). At the same time, the clay $\varepsilon N d$ composition remained near constant and high (-2). In contrast, silt $\varepsilon N d$ display an abrupt trend towards lower (less radiogenic) isotopic signatures, by about 3 epsilon units. This shift, associated with the 
decrease of $\mathrm{Ti} / \mathrm{Ca}$ ratio, can hence only be explained by a major reduction in the export of coarse-grained particles from the Ethiopian Traps source region, together with presumably more important sediment contributions from the Sahara dust, or from the Bahr el Jebel/White Nile. Accordingly, during humid periods, the Nile flood-induced silty deposits are similar (higher $\varepsilon N d$ values) than clay fraction, showing a strong hydro-systems' reactivation in Ethiopian Highlands in link to high insolation patterns (Mologni et al., 2020).

Overall, during the YD, the observed size-dependent trends observed for $\mathrm{Nd}$ isotopes and mineralogical investigations appear in agreement with a possible reduced rainfall resulting in weaker river transport energy of the silts derived for the Ethiopian Traps. Contrarily, the origin and the transport of suspended clays from the Ethiopian Highlands appeared to have remained globally unchanged. This may suggest that the onset of arid conditions in the Ethiopian Highlands led to reduced transport of coarse particles by the Blue Nile river in link with reduced hydrological activity.

Lower $\varepsilon N d$ values of the silt fraction during arid periods may be the result of combined climatic and geomorphic processes occurring along the Nile River headwaters. Higher precipitations over the 'Equatorial' Nile (Bahr el Jebel/White Nile; $4^{\circ} \mathrm{S}-3^{\circ} \mathrm{N}$; Fig. 1) supported by the ITCZ southward migration, with respect to northern Blue Nile sources (9$15^{\circ} \mathrm{N}$ ), would be the hydro-climatic driver of this process. However, Williams (2019) indicated that during White Nile low flow periods, the Sudd swamps dried out, taking a few centuries to re-establish during the subsequent humid phase. Thus, the absence of the filtering swamps effect could have permitted an enhanced coarse particle discharge, making the Bahr el Jebel/White Nile hydro-sedimentary system excessively reactive to precipitations during or immediately after arid periods. Finally, low silt $\varepsilon N d$ during arid periods can be even attributable to an aeolian coarser source derived from the Saharan Metacraton or from the Red Sea Hills erosion (Macgregor, 2012; Palchan et al., 2013). 
Our results show that the combination of $\mathrm{Nd}$ isotopic compositions in both clay and silt size fractions constitutes a powerful tool for evidencing differential transport processes mechanisms in response to the YD climatic forcing.

\subsubsection{Threshold effects on transport related to insolation minima and maxima}

The low insolation period ranged between 50 and 40 kyrs BP is characterized in MS27PT core by a slight decrease only of both clay Ti/Ca ratio and $\varepsilon N d$ (Fig. 6e, f and g). The lack of significant geochemical changes during this specific arid period could be explained by a threshold effect of insolation on sediment transport efficiency. Indeed, the decrease in insolation around $445 \mathrm{~W} / \mathrm{m}^{2}$ (and corresponding monsoon activity) was not as strong as during other arid periods when the $15^{\circ} \mathrm{N}$ insolation value was much weaker in magnitude (< $440 \mathrm{~W} / \mathrm{m}^{2}$; Fig. 6e). From an astronomic point of view, at $45 \mathrm{kyr} \mathrm{BP}$, the eccentricity was low and modulated the precession, with consequently a small decrease of the insolation value (Fig. $6 \mathrm{a}, \mathrm{b}$ and $\mathrm{c})$. This particular orbital configuration and the resulting small decrease in local insolation could be responsible for a limited increase of the Nile flood activity.

A similar threshold effect might have occurred during periods of maxima insolation, which are usually expected to be related to humid climate and development of Sapropel layers in the Eastern Mediterranean Sea (Emeis et al., 2003; Rohling et al., 2015; Rossignol-Strick et al., 1982). Five high insolation periods occurred during the last $110 \mathrm{kyr}$ (Fig. 6e). However, only 3 sapropel layers (S1, S3, S4) were recorded in the MS27PT sediment, as inferred from their high sulphur contents (Fig. 6d) suggesting a non-linear response of sapropel events to insolation patterns. The absence of sulfur along with a slight increase in Ti/Ca ratio during the high insolation period centered around $55 \mathrm{kyr}$ and around $33 \mathrm{kyr}$ suggest that particulate and freshwater river discharges did not increase significantly at that time, in contrast to S1, S3 and 
S4. Similarly, a threshold effect during insolation maxima periods was evidenced in the Sanbao-Hulu speleothem (Wang et al., 2008), indicating possible decoupling between insolation and monsoon activity (Ziegler et al., 2010).

From a continental point of view of the Nile river functioning, the installation of the Gezira mega-fan (in the lower Blue and White valleys) at $41 \mathrm{ka}$ and also at around $55 \mathrm{ka}$, with an overbank flooding suggesting wetter condition upstream in the Blue Nile headwaters (Williams et al., 2015). Geomorphological study evidences the presence of the Dinder, a seasonal tributary attesting increase in terrigenous and freshwater inputs in the lower Blue Nile region (Williams, 2019; Williams et al., 2015). However, the deltaic sediments do not record an enhanced sediment transport at that time. Also, at 33 kyrs BP the obliquity was low (inclination of the earth's axe of rotation is of $22.5^{\circ}$ : Fig. $6 \mathrm{~b}$ ) and could modulate the precession, with consequently a smaller increase of the insolation value compared to the AHP. Thus, this particular orbital configuration could be responsible for a limited increase in monsoon intensity and associated Nile flood activity, explaining the more negative $\varepsilon N d$ value of -4 compared to the AHP.

It is not excluded that geomorphological changes along the White Nile branch may explain the subtle $\varepsilon N d$ variations observed among humid periods. For example, towards $27 \mathrm{kyrs}$, there is good evidence of very high White Nile flow synchronous with a phase of alluvial fan activity near Jebelein (Williams et al., 2010). As indicated by Williams (2019), during humid periods the exceptionally high Blue Nile flow caused a dam effect on White Nile water/sediment inputs, creating a vast seasonal lake in which fine mud accumulated. During arid periods, reduced Blue Nile flow allows the Withe Nile mega-lake regression and the erosion and transport of low radiogenic $(\varepsilon N d)$ sediments contained within it. Similar to Sudd swamps functioning during YD (see Section 5.1.2), the White Nile solid discharge would have been subjected to hydro-geomorphic processes partially decoupled from climatic 

sediments during arid periods.

\subsubsection{Sources vs weathering}

forcing, which could explain variations in more negative $\varepsilon N d$ values recorded in the NDSF

\subsection{Relationships between climate and continental weathering}

Measured variations of weathering proxies such as mobile/immobile element ratios (e.g. $\mathrm{Mg} / \mathrm{Ti}$ and $\mathrm{K} / \mathrm{Ti}$ ) and $\delta^{7} \mathrm{Li}$ in clays can be equally affected by changes in weathering conditions and by sediment provenance. In core MS27PT, the increase of clay K/Ti ratios during arid periods (see yellow bands in Fig. 2) could possibly be explained by enhanced contribution of K-rich illite from presumably source regions characterized by relatively low $\varepsilon N d$ values (Saharan dust and/or Bahr el Jebel/White Nile River particles), despite the fact that there is no clear relationships between illite contents and insolation (Figs. 2 and 4, Table $\mathrm{S} 2$ ). Alternatively, downcore $\mathrm{K} / \mathrm{Ti}$ variations could result from changes in the leaching degree, since potassium is an alkali element mostly mobile during chemical weathering (Fig. 2e). As already discussed in Bastian et al., (2017), evidence that the clay K/Ti trend in core MS27PT evolves similarly with $\mathrm{Mg} / \mathrm{Ti}$ first supports that they both are controlled by weathering. This is because $\mathrm{K}$ and $\mathrm{Mg}$ in clay-size fractions are preferentially hosted by distinct secondary mineral phases, e.g illite vs smectite, respectively. It should be noted that the amplitude of the variations in $\mathrm{K} / \mathrm{Ti}$ and $\mathrm{Mg} / \mathrm{Ti}$ ratios during the MIS4 arid period is similar to HS4 and HS5 Heinrich events, whereas the amplitude of the Nd variations remain small for HS4 and HS5 (Fig. 2). This suggests that clay K/Ti and Mg/Ti ratios may be controlled by the two processes (change in source and in weathering), but at a different degree, depending on the climate event intensity or location. 
Concerning the control of $\mathrm{Li}$ isotopes, the $\varepsilon \mathrm{Nd}$ vs $\delta^{7} \mathrm{Li}$ diagram (Fig. 7) shows that there is no simple correlation between these proxies. Clay samples with similar $\delta^{7} \mathrm{Li}$ values $\left(\sim 2 \%{ }_{0} \pm 0.5 \%\right.$ o $)$ can display a wide range of $\varepsilon N d$ values (Fig. 7a), and vice versa. Also, there is no visible relationship between $\delta^{7} \mathrm{Li}$ and clay $\mathrm{Li} / \mathrm{Al}$, in contrast with river SPM, which are mostly controlled by mineral mixing (Dellinger et al., 2017) (see SI). As a consequence, variations in clay $\delta^{7} \mathrm{Li}$ compositions during the last $110 \mathrm{kyrs}$ most likely reflect weathering variations, in agreement with previous studies (e.g. Pogge von Strandmann et al., 2017, 2010, 2020; Dellinger et al., 2017, 2015, 2014; Bastian et al., 2017; Vigier et al., 2009). This is particularly evident for several specific arid periods (H2, H4, LGM) during which clay $\delta^{7} \mathrm{Li}$ exhibit a large range of values but without any particular change in $\varepsilon N d$ (Figs. $7 b$ and 9). These arid periods are also characterized by the highest $\delta^{7} \mathrm{Li}$ values measured in clays. As described in the Introduction, these high $\delta^{7} \mathrm{Li}$ values reflect a more incongruent weathering and a lower (leaching / neoformation) ratios, and are consistent with lower leaching rates under less intensive monsoonal precipitation. In contrast, no clear systematics can be highlighted for humid periods characterized by high and homogeneous $\varepsilon \mathrm{Nd}$ values, since the AHP clays display significantly lower $\delta^{7} \mathrm{Li}$ values compared to the 80 and $105 \mathrm{kyr}$ humid periods (MIS 5a and 5c; Figs. 6 and 9).

\subsubsection{Impact of monsoon intensity oscillation and of temperature variations}

For the AHP ( 14.5 - 6 kyrs), the MIS 5a ( 86 - 75 kyrs) and the MIS 5c ( 96 kyrs) humid periods, elevated insolation maxima indicate higher monsoonal precipitation and freshwater discharge across the Nile River Basin, as traced by more radiogenic Nd signature, during sapropels S1, S3 and S4 (Fig. 6). Thus, one would expect that these three humid periods were associated with low clay $\delta^{7} \mathrm{Li}$ values, as observed during the AHP and explained by higher leaching rate (Bastian et al., 2017). However, during MIS5a and 5c, clay $\delta^{7} \mathrm{Li}$ are significantly 
higher $(\sim 3.5 \%)$ than during the AHP $(\sim 1.7 \%$ ). This feature may be related with the observed differences in the magnitude of insolation maxima: $470 \mathrm{~W} / \mathrm{m}^{2}$ during the AHP vs $480 \mathrm{~W} / \mathrm{m} 2$ during MIS5a and 5c, leading to distinct variations of the precipitation pattern (Fig. 6e).

An alternative explanation would be that soil and vegetation covers prior to the onset of increasing monsoon were different for each of these periods, resulting in a different weathering response. Since the Eemien period and before the onset of S4 and S3, environmental conditions were warmer and probably more humid than during the Last Glacial Period ( 75 - 25 kyrs BP; Kutzbach et al., 2020; Lisiecki and Raymo, 2005). Indeed, in North and West Africa, the Last Interglacial period (until MIS 5d; 130 - 110 kyrs BP) was characterized by enhanced humidity and by the expansion of rain forest (Dupont et al., 2000) composed by common $\mathrm{C}_{3}$ plants, suggesting the spread of trees and soil development in the sub-Saharan area (Castañeda et al., 2009a; Williams, 2019). After 110 kyrs BP, the response of weathering to precipitation changes between MIS 5c and 5a periods could have been higher than during the AHP, which followed the LGM period characterized by reduced soil thickness and vegetation cover. Additional work would be needed to further explore these aspects.

Another interesting feature displayed by Li isotopes downcore MS27PT is the progressive decrease of the clay $\delta^{7} \mathrm{Li}$ baseline values between $110 \mathrm{kyr}$ and $25 \mathrm{kyr}$, which appears to mimic the planktonic foraminiferal $\delta^{18} \mathrm{O}$ signal (Figs. 8a, 8c and S1). This covariation suggests an influence of regional temperature on the weathering incongruency ratio at the scale of the Nile Basin. Over the last $110 \mathrm{kyr}$, estimates for air temperatures in tropical Africa display variations in relation with glacial-interglacial climatic variability. These estimations are based on various proxy records from lake (Tierney et al., 2008) and marine (Hijmans et al., 2005; Molliex et al., 2019) sediments, and from Soreq cave speleothem reconstructions (Affek et al., 2008; Mcgarry et al., 2004; Pogge von Strandmann et al., 2017; Fig. 8b). Also, temperature in the last glacial tropical Africa was estimated to be about $3-5^{\circ} \mathrm{C}$ cooler than today (LGM, 
Kelly et al., 2014; Schefuß et al., 2005). Based on the above, we speculate that a progressive cooling in North-East Africa between $\sim 110$ and $\sim 25$ kyrs could possibly explain the progressive decrease of the $\delta^{7} \mathrm{Li}$ minima values, in response to gradual changes in soil conditions within the Nile Basin. This would be in agreement with a recent investigation of speleothems from the Soreq cave in Israel (Fig. 8b; Pogge von Strandmann et al., 2017), which suggested a weakening of continental weathering over glacial/interglacial cycles due to decreasing temperatures. Thus, in contrast to rainfall changes, which presumably result in rapid response of leaching rates, gradual temperature evolution can affect soil conditions and clay neoformation rates over the long-term only (>10kyr). Li isotopes in clay-size fractions from the NSDF therefore suggest a decoupled response of continental weathering to temperature and precipitation changes.

\subsubsection{Synchronous timing with Heinrich stadials}

During the last glacial period $(\sim 75-\sim 25$ kyrs BP), the evolution of global climate was punctuated by abrupt instabilities, recorded in the Greenland ice $\delta^{18} \mathrm{O}$ signals as DansgaardOeschger cycles (DO; Bond et al., 1993; Dansgaard et al., 1993). These cycles were characterized by the succession of rapid shifts towards higher (interstadial) and lower (stadial) temperature in the northern latitudes (Sanchez Goñi and Harrison, 2010), presumably resulting from changing ocean circulation patterns (e.g. Waelbroeck et al., 2018). Some DO stadials were associated with episodes of massive iceberg discharge in the North Atlantic (referred to as Heinrich Stadial [HS], Heinrich, 1988; Hemming, 2004). The HS events and other northern hemisphere cold episodes, such as the YD, were associated to arid conditions in northern Africa (Shanahan et al., 2015; Verschuren et al., 2009). The mechanism responsible for this aridification is still under debate. One explanation is that Atlantic Meridional Oceanic Circulation (AMOC) reduction at that time led to the southward 
migration of the ITCZ and monsoon rain belt, leading to regional aridification in North Africa, as testified by increase in the delivery of Saharan dust along the western African ocean margins (Collins et al., 2013; Heinrich et al., 2021; Le Quilleuc et al., submitted) or by $\delta \mathrm{D}_{\text {wax }}$ displayed by lake sediment records (Tierney et al., 2008). Instead, a recent study (Collins et al., 2017) suggests that reorganisation of the tropical jet stream and atmospheric circulation patterns may have played an important role in the monsoon variability at that time. This could explain the sudden shifts towards aridification in northern Africa during HS events. In any case, the fact is that North Atlantic cooling episodes are recorded in sedimentary archives from tropical regions in Africa. For instance, $\delta \mathrm{D}_{\text {wax }}$ records in Lake Tanganyika and Lake Challa (Tierney et al., 2008) indicate reduced precipitation during HS1 $(\approx 16$ kyrs) to HS5 ( $\approx 47$ kyrs). Desiccation of Lake Tana during HS1 coincides with drying of Lake Victoria, source of the White Nile water, underlining the sensitivity of the entire Nile basin to climatic extremes (Lamb et al., 2018; Stager and Johnson, 2008; Talbot and Lærdal, 2000).

In NDSF core MS27PT, weathering proxy records $\left(\mathrm{Mg} / \mathrm{Ti}, \mathrm{K} / \mathrm{Ti}\right.$ and $\left.\delta^{7} \mathrm{Li}\right)$ are clearly in phase with the North Atlantic climate instabilities (see Fig. 9). The observed shift towards heavier (higher) clay $\delta^{7} \mathrm{Li}$ values during arid periods is consistent with reduced leaching under more arid conditions. The variation amplitude of weathering proxies is quite large during HS1, HS2, HS4 and HS5 events, and comparatively smaller during HS3. This observation is comparable to aeolian dust records from the western African margin (Collins et al., 2013; Heinrich et al., 2021). For some of these events (e.g. HS4) clay $\varepsilon_{N d}$ vary little, suggesting a lack of control from clay provenance, as detailed in section 5.2.1, but this would need to be refined at a higher temporal resolution. Overall, these observations reinforce the idea that past $\delta^{7} \mathrm{Li}$ variations have been primarily driven by monsoon intensity and suggest that abrupt 
661

662 influenced weathering processes in northern Africa.

663

\section{Conclusions} $\delta^{7} \mathrm{Li}$ values during the $\sim 3000 \mathrm{~km}$ transport by the Nile River.

climate changes - originally initiated in the northern hemisphere high-latitudes - may have

Our results suggest a temporal synchronization between North Atlantic climate variations, monsoon variability and silicate weathering in northern Africa. Evidence for a timely response of chemical weathering to tropical monsoon has important implications for predicting the possible future impact of global warming in tropical regions. A recent modeling study (Defrance et al., 2017) predicts a future reduction of rainfall in northern Africa (Sahel, Ethiopia) due to temperature anomalies and changes in wind direction. Since these areas are densely populated and heavily dependent on rainfall and water availability, a rapid change in soil resources may have strong consequences for local populations.

We applied various geochemical proxies $\left(\delta^{7} \mathrm{Li}, \varepsilon \mathrm{Nd}\right.$ and elementary ratios) to clay-size sediment fractions from both marine (core MS27PT) and lacustrine (Lake Tana) sediments in order to better understand the impact of African monsoon fluctuations on erosion and chemical weathering processes within the Nile Basin during the Late Quaternary.

Based on $\mathrm{Nd}$ isotopes, we showed that the Ethiopian Traps area represented the main contributor of clays to the NDSF for the last 110,000 years. The use of Li isotopes as weathering proxies in this basin was evaluated by comparing Li isotope measurements from core MS27PT and Lake Tana sediment records, indicating no significant change of the clay

We find that fluctuations of clay-size particle contributions to the Nile Delta are mainly driven by orbital precession cycle, which controls the African monsoon intensity variations. Nevertheless our results indicate a non-linear response of the Nile sources and chemical 
weathering to the insolation forcing. Finally, a decoupling between temperature and precipitation is found concerning their respective impact on chemical weathering. A decrease of mineral leaching rates in soils is inferred from Li isotopes during several Heinrich Stadials, with no significant time lag relative to North Atlantic climatic events. This synchronous timing evidences a rapid response of continental weathering to hydroclimate changes.

\section{Acknowledgments}

This work was financially supported by BQR Geoazur and OCA, INSU-SYSTER grants and the ANR INTOCC (ANR-15-CE31-0013). The MS27PT core was recovered during the MIMES cruise. We thank A. De Prunelé and Y. Germain for assistance during MC-ICPMS analyses at IFREMER. O. Bruguier from the Montpellier university is acknowledged for assistance during MC-ICPMS analyses realized at the AETE-ISO platform.

\section{Author contributions}

Marie Revel and Nathalie Vigier led the project and helped with interpretation and writing. Luc Bastian performed sediment sampling, treatment and all Li isotope analyses. MarieEmmanuelle Kerros helped with the sediment pre-treatment and clay extractions. Luc Bastian and Carlo Mologni led the writing. Germain Bayon performed Nd isotope analyses on Nile delta clays and helped with interpretation. Delphine Bosch was in charge with $\mathrm{Nd}$ isotope analyses of Tana Lake sediments. Christophe Colin performed clay mineralogy in Nile Delta sediments and helped with interpretation. Henry Lamb provided us the lake Tana samples already dated. All authors contributed to data interpretation and writing finalization. 
709 Luc Bastian and Carlo Mologni, on behalf of all authors of the paper, declare that there are no 710 competing financial interests in relation to the work described. 
Abdelsalam, M.G., Liégeois, J.-P., Stern, R.J., 2002. The Saharan Metacraton. Journal of African Earth Sciences 34, 119-136. https://doi.org/10.1016/S0899-5362(02)00013-1

Affek, H.P., Bar-matthews, M., Ayalon, A., Matthews, A., Eiler, J.M., 2008. Glacial / interglacial temperature variations in Soreq cave speleothems as recorded by 'clumped isotope' thermometry. Geochimica et Cosmochimica Acta 72, 5351-5360. https://doi.org/10.1016/j.gca.2008.06.031

Almogi-Labin, A., Bar-Matthews, M., Shriki, D., Kolosovsky, E., Paterne, M., Schilman, B., Ayalon, A., Aizenshtat, Z., Matthews, A., 2009. Climatic variability during the last $\sim 90$ ka of the southern and northern Levantine Basin as evident from marine records and speleothems. Quaternary Science Reviews 28, 2882-2896. https://doi.org/10.1016/j.quascirev.2009.07.017

Andersen, K.K., Azuma, N., and North Greenland Ice Core Project members, 2004. High-resolution record of Northern Hemisphere climate extending into the last interglacial period. Nature. https://doi.org/10.1038/nature02805

Bahr, A., Kaboth, S., Jiménez-Espejo, F.J., Sierro, F.J., Voelker, A.H.L., Lourens, L., Röhl, U., Reichart, G.J., Escutia, C., Hernández-Molina, F.J., Pross, J., Friedrich, O., 2015. Persistent monsoonal forcing of mediterranean outflow water dynamics during the late Pleistocene. Geology 43, 951-954. https://doi.org/10.1130/G37013.1

Balter, V., Vigier, N., 2014. Natural variations of lithium isotopes in a mammalian model. Metallomics 6, 582-586. https://doi.org/10.1039/c3mt00295k

Bastian, L., Revel, M., Bayon, G., Dufour, A., Vigier, N., 2017. Abrupt response of chemical weathering to Late Quaternary hydroclimate changes in northeast Africa. Scientific Reports 7, 44231. https://doi.org/10.1038/srep44231

Bastian, L., Vigier, N., Revel, M., Bayon, G., 2018. Lithium Isotope Composition of Marine Biogenic Carbonates and Related Reference Materials 42, 403-415. https://doi.org/10.1111/ggr.12218

Bastian, L., Vigier, N., Revel, M., Yirgu, G., Ayalew, D., Pik, R., 2019. Chemical erosion rates in the upper Blue Nile Basin and related atmospheric $\mathrm{CO} 2$ consumption. Chemical Geology 518, 1931. https://doi.org/10.1016/j.chemgeo.2019.03.033

Bayon, G., Dennielou, B., Etoubleau, J., Ponzevera, E., Toucanne, S., Bermell, S., 2012. Intensifying weathering and land use in iron age Central Africa. Science 335, 1219-1222. https://doi.org/10.1126/science.1215400

Bayon, G., Toucanne, S., Skonieczny, C., André, L., Bermell, S., Cheron, S., Dennielou, B., Etoubleau, J., Freslon, N., Gauchery, T., Germain, Y., Jorry, S.J., Ménot, G., Monin, L., Ponzevera, E., Rouget, M.L., Tachikawa, K., Barrat, J.A., 2015. Rare earth elements and neodymium isotopes in world river sediments revisited. Geochimica et Cosmochimica Acta 170, 17-38. https://doi.org/10.1016/j.gca.2015.08.001

Beaulieu, E., Goddëris, Y., Donnadieu, Y., Labat, D., Roelandt, C., 2012. High sensitivity of the continental-weathering carbon dioxide sink to future climate change. Nature Climate Change 2, 346-349. https://doi.org/10.1038/nclimate1419

Berger, A., Loutre, M.F., 1991. Insolation values for the climate of the last 10 million years. Quaternary Science Reviews 10, 297-317. https://doi.org/10.1016/0277-3791(91)90033-Q

Berke, M.A., Johnson, T.C., Werne, J.P., Grice, K., Schouten, S., Sinninghe Damsté, J.S., 2012. Molecular records of climate variability and vegetation response since the Late Pleistocene in the Lake Victoria basin, East Africa. Quaternary Science Reviews 55, 59-74. https://doi.org/10.1016/j.quascirev.2012.08.014 
Blanchet, C.L., Contoux, C., Leduc, G., 2015. Runoff and precipitation dynamics in the Blue and White Nile catchments during the mid-Holocene: A data-model comparison. Quaternary Science Reviews 130, 222-230. https://doi.org/10.1016/j.quascirev.2015.07.014

Blanchet, C.L., Frank, M., Schouten, S., 2014. Asynchronous changes in vegetation, runoff and Erosion in the Nile River watershed during the Holocene. PLoS ONE 9, 1-18. https://doi.org/10.1371/journal.pone.0115958

Blanchet, C.L., Osborne, A.H., Tjallingii, R., Ehrmann, W., Friedrich, T., Timmermann, A., Brückmann, W., Frank, M., 2021. Drivers of river reactivation in North Africa during the last glacial cycle. Nature Geoscience 1-7. https://doi.org/10.1038/s41561-020-00671-3

Blanchet, C.L., Tjallingii, R., Frank, M., Lorenzen, J., Reitz, A., Brown, K., Feseker, T., Brückmann, W., 2013. High- and low-latitude forcing of the Nile River regime during the Holocene inferred from laminated sediments of the Nile deep-sea fan. Earth and Planetary Science Letters 364, 98-110. https://doi.org/10.1016/j.epsl.2013.01.009

Blanchet, C.L., Tjallingii, R., Schleicher, A.M., Schouten, S., Frank, M., Brauer, A., 2020. Deoxygenation dynamics above the western Nile deep-sea fan during sapropel S1 at seasonal to millennial time-scales (preprint). Teleconnections/Marine Archives/Holocene. https://doi.org/10.5194/cp-2020-114

Bond, G., Broecker, W., Johnsen, S., McManus, J., Labeyrie, L., Jouzel, J., Bonani, G., 1993. Correlations between climate record from North Atlantic sediments and Greenland ice. Nature 365, 143-147.

Bouchez, J., Blanckenburg, F. von, Schuessler, J.A., 2013. Modeling novel stable isotope ratios in the weathering zone. American Journal of Science 313, 267-308. https://doi.org/10.2475/04.2013.01

Bouimetarhan, I., Prange, M., Schefuß, E., Dupont, L., Lippold, J., Mulitza, S., Zonneveld, K., 2012. Sahel megadrought during Heinrich Stadial 1: Evidence for a three-phase evolution of the low- and mid-level West African wind system. Quaternary Science Reviews 58, 66-76. https://doi.org/10.1016/j.quascirev.2012.10.015

Bouvier, A., Vervoort, J.D., Patchett, P.J., 2008. The Lu-Hf and Sm-Nd isotopic composition of CHUR: Constraints from unequilibrated chondrites and implications for the bulk composition of terrestrial planets. Earth and Planetary Science Letters 273, 48-57. https://doi.org/10.1016/j.epsl.2008.06.010

Carignan, J., Vigier, N., Millot, R., 2007. Three secondary reference materials for lithium isotope measurements: Li7-N, Li6-N and LiCl-N solutions. Geostandards and Geoanalytical Research 31, 7-12. https://doi.org/10.1111/j.1751-908X.2007.00833.x

Castañeda, I.S., Mulitza, S., Schefuß, E., Santos, R.A.L. dos, Damsté, J.S.S., Schouten, S., 2009a. Wet phases in the Sahara/Sahel region and human migration patterns in North Africa. PNAS 106, 20159-20163. https://doi.org/10.1073/pnas.0905771106

Castañeda, I.S., Schouten, S., Pätzold, J., Lucassen, F., Kasemann, S., Kuhlmann, H., Schefuß, E., 2016. Hydroclimate variability in the Nile River Basin during the past 28,000 years. Earth and Planetary Science Letters 438, 47-56. https://doi.org/10.1016/j.epsl.2015.12.014

Castañeda, I.S., Werne, J.P., Johnson, T.C., Filley, T.R., 2009b. Late Quaternary vegetation history of southeast Africa: The molecular isotopic record from Lake Malawi. Palaeogeography, Palaeoclimatology, Palaeoecology 275, 100-112. https://doi.org/10.1016/j.palaeo.2009.02.008

Caves Rugenstein, J.K., Ibarra, D.E., von Blanckenburg, F., 2019. Neogene cooling driven by land surface reactivity rather than increased weathering fluxes. Nature 571, 99-102. https://doi.org/10.1038/s41586-019-1332-y

Chauvel, C., Blichert-toft, J., 2001. A hafnium isotope and trace element perspective on melting of the depleted mantle. Earth and Planetary Science Letters 190.

Chen, Q., Liu, Z., Kissel, C., 2017. Clay mineralogical and geochemical proxies of the East Asian summer monsoon evolution in the South China Sea during Late Quaternary. Scientific Reports 7, 42083. https://doi.org/10.1038/srep42083 
Clift, P.D., Kulhanek, D.K., Zhou, P., Bowen, M.G., Vincent, S.M., Lyle, M., Hahn, A., 2020. Chemical weathering and erosion responses to changing monsoon climate in the Late Miocene of Southwest Asia. Geol. Mag. 157, 939-955. https://doi.org/10.1017/S0016756819000608 Clift, P.D., Wan, S., Blusztajn, J., 2014. Reconstructing chemical weathering, physical erosion and monsoon intensity since $25 \mathrm{Ma}$ in the northern South China Sea: A review of competing proxies. Earth-Science Reviews 130, 86-102. https://doi.org/10.1016/j.earscirev.2014.01.002

Collins, J.A., Govin, A., Mulitza, S., Heslop, D., Zabel, M., Hartmann, J., Röhl, U., Wefer, G., 2013. Abrupt shifts of the Sahara-Sahel boundary during Heinrich stadials. Climate of the Past 9 , 1181-1191. https://doi.org/10.5194/cp-9-1181-2013

Collins, J.A., Prange, M., Caley, T., Gimeno, L., Beckmann, B., Mulitza, S., Skonieczny, C., Roche, D., Schefuß, E., 2017. Rapid termination of the African Humid Period triggered by northern highlatitude cooling. Nature Communications 8. https://doi.org/10.1038/s41467-017-01454-y

Collins, J.A., Schefuß, E., Heslop, D., Mulitza, S., Prange, M., Zabel, M., Tjallingii, R., Dokken, T.M., Huang, E., MacKensen, A., Schulz, M., Tian, J., Zarriess, M., Wefer, G., 2011. Interhemispheric symmetry of the tropical African rainbelt over the past 23,000 years. Nature Geoscience 4, 42-45. https://doi.org/10.1038/ngeo1039

Cornuault, M., Vidal, L., Tachikawa, K., Licari, L., Rouaud, G., Sonzogni, C., Revel, M., 2016. Deep water circulation within the eastern Mediterranean Sea over the last 95kyr: New insights from stable isotopes and benthic foraminiferal assemblages. Palaeogeography, Palaeoclimatology, Palaeoecology 459, 1-14. https://doi.org/10.1016/j.palaeo.2016.06.038

Costa, K., Russell, J., Konecky, B., Lamb, H., 2014. Isotopic reconstruction of the African Humid Period and Congo Air Boundary migration at Lake Tana, Ethiopia. Quaternary Science Reviews 83, 58-67. https://doi.org/10.1016/j.quascirev.2013.10.031

Dansgaard, W., Johnsen, S.J., Clausen, H.B., Dahl-Jensen, D., Gundestrup, N.S., Hammer, C.U., Hvidberg, C.S., Steffensen, J.P., Sveinbjörnsdottir, A.E., Jouzel, J., Bond, G., 1993. Evidence for general instability of past climate from a 250-kyr ice-core record. Nature 364, 218-220.

De Lange, G.J., Thomson, J., Reitz, A., Slomp, C.P., Speranza Principato, M., Erba, E., Corselli, C., 2008. Synchronous basin-wide formation and redox-controlled preservation of a Mediterranean sapropel. Nature Geoscience 1, 606-610. https://doi.org/10.1038/ngeo283

Defrance, D., Ramstein, G., Charbit, S., Vrac, M., Famien, A.M., Sultan, B., Swingedouw, D., Dumas, C., Gemenne, F., Alvarez-Solas, J., Vanderlinden, J.-P., 2017. Consequences of rapid ice sheet melting on the Sahelian population vulnerability. Proceedings of the National Academy of Sciences 114, 6533-6538. https://doi.org/10.1073/pnas.1619358114

Dellinger, M., Bouchez, J., Gaillardet, J., Faure, L., Moureau, J., 2017. Tracing weathering regimes using the lithium isotope composition of detrital sediments. Geology 45, 411-414. https://doi.org/10.1130/G38671.1

Dellinger, M., Gaillardet, J., Bouchez, J., Calmels, D., Louvat, P., Dosseto, A., Gorge, C., Alanoca, L., Maurice, L., 2015. Riverine Li isotope fractionation in the Amazon River basin controlled by the weathering regimes. Geochimica et Cosmochimica Acta 164, 71-93. https://doi.org/10.1016/j.gca.2015.04.042

Dellinger, M., Gaillardet, J.Ô., Bouchez, J., Calmels, D., Galy, V., Hilton, R.G., Louvat, P., FranceLanord, C., 2014. Lithium isotopes in large rivers reveal the cannibalistic nature of modern continental weathering and erosion. Earth and Planetary Science Letters 401, 359-372. https://doi.org/10.1016/j.epsl.2014.05.061

Demenocal, P., Ortiz, J., Guilderson, T., Adkins, J., Sarnthein, M., Baker, L., Yarusinsky, M., 2000. Abrupt onset and termination of the African Humid Period: Rapid climate responses to gradual insolation forcing. Quaternary Science Reviews 19, 347-361. https://doi.org/10.1016/S0277-3791(99)00081-5

Dosseto, A., Vigier, N., Joannes-Boyau, R., Moffat, I., Singh, T., Srivastava, P., 2015. Rapid response of silicate weathering rates to climate change in the Himalaya. Geochemical Perspectives Letters 10-19. https://doi.org/10.7185/geochemlet.1502 
Ducassou, E., Migeon, S., Mulder, T., Murat, A., Capotondi, L., Bernasconi, S.M., Mascle, J., 2009. Evolution of the nile deep-sea turbidite system during the late quaternary: Influence of climate change on fan sedimentation. Sedimentology 56, 2061-2090. https://doi.org/10.1111/j.1365-3091.2009.01070.x

Ducassou, E., Mulder, T., Migeon, S., Gonthier, E., Murat, A., Revel, M., Capotondi, L., Bernasconi, S.M., Mascle, J., Zaragosi, S., 2008. Nile floods recorded in deep Mediterranean sediments. Quaternary Research 70, 382-391. https://doi.org/10.1016/j.yqres.2008.02.011

Dupont, L.M., Jahns, S., Marret, F., Ning, S., 2000. Vegetation change in equatorial West Africa: timeslices for the last 150 ka. Palaeogeography, Palaeoclimatology, Palaeoecology 155, 95-122. https://doi.org/10.1016/S0031-0182(99)00095-4

Dupuis, R., Benoit, M., Tuckerman, M.E., Méheut, M., 2017. Importance of a Fully Anharmonic Treatment of Equilibrium Isotope Fractionation Properties of Dissolved Ionic Species As Evidenced by Li+(aq). Accounts of Chemical Research 50, 1597-1605. https://doi.org/10.1021/acs.accounts.6b00607

Ehrmann, W., Schmiedl, G., Beuscher, S., Krüger, S., 2017. Intensity of African Humid Periods Estimated from Saharan Dust Fluxes. PLOS ONE 12, e0170989. https://doi.org/10.1371/journal.pone.0170989

Emeis, K.-C., Schulz, H., Struck, U., Rossignol-Strick, M., Erlenkeuser, H., Howell, M.W., Kroon, D., Mackensen, A., Ishizuka, S., Oba, T., Sakamoto, T., Koizumi, I., 2003. Eastern Mediterranean surface water temperatures and $\delta^{18} \mathrm{O}$ composition during deposition of sapropels in the late Quaternary: SST AND $\delta^{18}$ O OF MEDITERRANEAN SAPROPELS. Paleoceanography 18, n/a-n/a. https://doi.org/10.1029/2000PA000617

Faccenna, C., Glišović, P., Forte, A., Becker, T.W., Garzanti, E., Sembroni, A., Gvirtzman, Z., 2019. Role of dynamic topography in sustaining the Nile River over 30 million years. Nat. Geosci. https://doi.org/10.1038/s41561-019-0472-x

Fielding, L., Najman, Y., Millar, I., Butterworth, P., Ando, S., Padoan, M., Barfod, D., Kneller, B., 2017. A detrital record of the Nile River and its catchment. Journal of the Geological Society 174, 301-317. https://doi.org/10.1144/jgs2016-075

Foerster, V., Junginger, A., Langkamp, O., Gebru, T., Asrat, A., Umer, M., Lamb, H.F., Wennrich, V., Rethemeyer, J., Nowaczyk, N., Trauth, M.H., Schaebitz, F., 2012. Climatic change recorded in the sediments of the Chew Bahir basin, southern Ethiopia, during the last 45,000 years. Quaternary International 274, 25-37. https://doi.org/10.1016/j.quaint.2012.06.028

Garcin, Y., Vincens, A., Williamson, D., Buchet, G., Guiot, J., 2007. Abrupt resumption of the African Monsoon at the Younger Dryas-Holocene climatic transition. Quaternary Science Reviews 26, 690-704. https://doi.org/10.1016/j.quascirev.2006.10.014

Garzanti, E., Andò, S., Padoan, M., Vezzoli, G., El Kammar, A., 2015a. The modern Nile sediment system: Processes and products. Quaternary Science Reviews 130, 9-56. https://doi.org/10.1016/j.quascirev.2015.07.011

Garzanti, E., Andò, S., Padoan, M., Vezzoli, G., El Kammar, A., 2015b. The modern Nile sediment system: Processes and products. Quaternary Science Reviews 130, 9-56. https://doi.org/10.1016/j.quascirev.2015.07.011

Gasse, F., 2000. Hydrological changes in the African tropiccs since the Last Glacial Maximum. Quaternary Science Reviews 19, 189-211.

Ghilardi, M., Boraik, M., 2011. Reconstructing the holocene depositional environments in the western part of Ancient Karnak temples complex (Egypt): A geoarchaeological approach. Journal of Archaeological Science 38, 3204-3216. https://doi.org/10.1016/j.jas.2011.06.007

Grousset, F.E., Biscaye, P.E., 2005. Tracing dust sources and transport patterns using Sr, Nd and Pb isotopes. Chemical Geology 222, 149-167. https://doi.org/10.1016/j.chemgeo.2005.05.006

Grousset, F.E., Biscaye, P.E., Zindler, A., Prospero, J., Chester, R., 1988. Neodymium Isotopes As Tracers in Marine-Sediments and Aerosols - North-Atlantic. Earth and Planetary Science Letters 87, 367-378. https://doi.org/10.1016/0012-821x(88)90001-5 
Hamann, Y., Ehrmann, W., Schmiedl, G., Kuhnt, T., 2009. Modern and late Quaternary clay mineral distribution in the area of the SE Mediterranean Sea. Quaternary Research 71, 453-464. https://doi.org/10.1016/j.yqres.2009.01.001

Heinrich, Hartmut, 1988. Origin and Consequences of Cyclic Ice Rafting in the Northeast Atlantic Ocean During the Past 130,000 Years. Quat. res. 29, 142-152. https://doi.org/10.1016/00335894(88)90057-9

Heinrich, $\mathrm{H}, 1988$. Origin and Consequences of Cyclic Ice Rafting in the Northeast Atlantic-Ocean During the Past 130,000 Years. Quaternary Research 29, 142-152. https://doi.org/10.1016/0033-5894(88)90057-9

Heinrich, H., Schmidt, C., Ziemen, F., Mikolajewicz, U., Roettig, C.-B., 2021. Massive deposition of Sahelian dust on the Canary Island Lanzarote during North Atlantic Heinrich Events. Quat. res. 1-16. https://doi.org/10.1017/qua.2020.100

Hemming, S.R., 2004. Heinrich events: Massive late Pleistocene ditritus layers of the North Atlanitc and their global cliamate imprint. Reviews of Geophysics 42, 1-43. https://doi.org/10.1029/2003RG000128.1.INTRODUCTION

Hennekam, R., Donders, T.H., Zwiep, K., de Lange, G.J., 2015. Integral view of Holocene precipitation and vegetation changes in the Nile catchment area as inferred from its delta sediments. Quaternary Science Reviews 130, 189-199. https://doi.org/10.1016/j.quascirev.2015.05.031

Hijmans, R.J., Cameron, S.E., Parra, J.L., Jones, G., Jarvis, A., 2005. Very high resolution interpolated Climate surfeces for Global land areas. International Journal of Climatology 25, 1965-1978. https://doi.org/10.1002/joc.1276

Huh, Y., Chan, L.-H., Zhang, L., Edmond, J.M., 1998. Lithium and its isotopes in major world rivers: implications for weathering and the oceanic budget. Geochimica et Cosmochimica Acta 62, 2039-2051. https://doi.org/10.1016/S0016-7037(98)00126-4

Johnson, P.R., Andresen, A., Collins, A.S., Fowler, A.R., Fritz, H., Ghebreab, W., Kusky, T., Stern, R.J., 2011. Late Cryogenian-Ediacaran history of the Arabian-Nubian Shield: A review of depositional, plutonic, structural, and tectonic events in the closing stages of the northern East African Orogen. Journal of African Earth Sciences 61, 167-232. https://doi.org/10.1016/j.jafrearsci.2011.07.003

Johnson, T.C., Malala, J.O., 2009. Lake Turkana and Its Link to the Nile, in: Dumont, H.J. (Ed.), The Nile, Monographiae Biologicae. Springer Netherlands, Dordrecht, pp. 287-304. https://doi.org/10.1007/978-1-4020-9726-3_15

Kallel, N., Duplessy, J.C., Labeyrie, L., Fontugne, M., Paterne, M., Montacer, M., 2000. Mediterranean pluvial periods and sapropel formation over the last 200000 years. Palaeogeography, Palaeoclimatology, Palaeoecology 157, 45-58. https://doi.org/10.1016/S00310182(99)00149-2

Kelly, M.A., Russell, J.M., Baber, M.B., Howley, J.A., Loomis, S.E., Zimmerman, S., Nakileza, B., Lukaye, J., 2014. Expanded glaciers during a dry and cold Last Glacial Maximum in equatorial East Africa. Geology 42, 519-522. https://doi.org/10.1130/G35421E.1

Krom, M.D., Cliff, R.A., Eijsink, L.M., Herut, B., Chester, R., 1999. The characterisation of Saharan dust and Nile particulate matter in surface sediments from the Levantine basin using $\mathrm{Sr}$ isotopes. Marine Geology 155, 319-330.

Krom, M.D., Stanley, J.D., Cliff, R. a, Woodward, J.C., 2002. Nile $\{$ R\}iver Sediment Fluctuation over the Past 7000 yr and their Role in Sapropel Development. Geology 30, 71-74. https://doi.org/10.1130/0091-7613(2002)030<0071

Kutzbach, J.E., Guan, J., He, F., Cohen, A.S., Orland, I.J., Chen, G., 2020. African climate response to orbital and glacial forcing in 140,000-y simulation with implications for early modern human environments. Proc Natl Acad Sci USA 117, 2255-2264. https://doi.org/10.1073/pnas.1917673117

Lamb, H.F., Bates, C.R., Bryant, C.L., Davies, S.J., Huws, D.G., Marshall, M.H., Roberts, H.M., 2018. 150,000-year palaeoclimate record from northern Ethiopia supports early, multiple 
dispersals of modern humans from Africa. Scientific Reports 8, 1-7. https://doi.org/10.1038/s41598-018-19601-w

Lamb, H.F., Bates, C.R., Coombes, P. V., Marshall, M.H., Umer, M., Davies, S.J., Dejen, E., 2007. Late Pleistocene desiccation of Lake Tana, source of the Blue Nile. Quaternary Science Reviews 26, 287-299. https://doi.org/10.1016/j.quascirev.2006.11.020

Langgut, D., Almogi-Labin, A., Bar-Matthews, M., Weinstein-Evron, M., 2011. Vegetation and climate changes in the South Eastern Mediterranean during the Last Glacial-Interglacial cycle (86 ka): New marine pollen record. Quaternary Science Reviews 30, 3960-3972. https://doi.org/10.1016/j.quascirev.2011.10.016

Le Quilleuc, M., A., Bory, A., Philippe, S., Derimian, Y., Skonieczny, C., Petit, J.-E., Ponlevé, D., Diallo, A., Ndiaye, T., Quentin, L., Tribovillard, N., Bout-Roumazeilles, V., submitted. Major element signatures of silicate dust deposited on the West African margin: links with transport patterns and provenance regions. Journal of Geophysical Research.

Li, G., West, A.J., 2014. Evolution of Cenozoic seawater lithium isotopes: Coupling of global denudation regime and shifting seawater sinks. Earth and Planetary Science Letters 401, 284-293. https://doi.org/10.1016/j.epsl.2014.06.011

Limmer, D.R., Köhler, C.M., Hillier, S., Moreton, S.G., Tabrez, A.R., Clift, P.D., 2012. Chemical weathering and provenance evolution of Holocene-Recent sediments from the Western Indus Shelf, Northern Arabian Sea inferred from physical and mineralogical properties. Marine Geology 326-328, 101-115. https://doi.org/10.1016/j.margeo.2012.07.009

Lisiecki, L.E., Raymo, M.E., 2005. A Pliocene-Pleistocene stack of 57 globally distributed benthic $\delta 180$ records. Paleoceanography 20, 1-17. https://doi.org/10.1029/2004PA001071

Liu, X., Rendle-B̈̈¿ $1 / 2 h$ ring, R., Kuhlmann, H., Li, A., 2017. Two phases of the Holocene East African Humid Period: Inferred from a high-resolution geochemical record off Tanzania. Earth and Planetary Science Letters 460, 123-134. https://doi.org/10.1016/j.epsl.2016.12.016

Macgregor, D.S., 2012. The development of the Nile drainage system: integration of onshore and offshore evidence. Petroleum Geoscience 18, 417-431. https://doi.org/10.1144/petgeo2011074

Marshall, M.H., Lamb, H.F., Huws, D., Davies, S.J., Bates, R., Bloemendal, J., Boyle, J., Leng, M.J., Umer, M., Bryant, C., 2011. Late Pleistocene and Holocene drought events at Lake Tana, the source of the Blue Nile. Global and Planetary Change 78, 147-161. https://doi.org/10.1016/j.gloplacha.2011.06.004

Martrat, B., Jimenez-Amat, P., Zahn, R., Grimalt, J.O., 2014. Similarities and dissimilarities between the last two deglaciations and interglaciations in the North Atlantic region. Quaternary Science Reviews 99, 122-134. https://doi.org/10.1016/j.quascirev.2014.06.016

Mascle, J., 2014. The Nile continental margin , a compendium compiled by Jean Mascle. Marine Geology 358, 2017.

Mcgarry, S., Bar-matthews, M., Matthews, A., 2004. Constraints on hydrological and paleotemperature variations in the Eastern Mediterranean region in the last 140 ka given by the $d$ D values of speleothem fluid inclusions 23, 919-934. https://doi.org/10.1016/j.quascirev.2003.06.020

McGee, D., deMenocal, P.B., Winckler, G., Stuut, J.B.W., Bradtmiller, L.I., 2013. The magnitude, timing and abruptness of changes in North African dust deposition over the last 20,000 yr. Earth and Planetary Science Letters 371-372, 163-176. https://doi.org/10.1016/j.epsl.2013.03.054

Migeon, S., Ducassou, E., Le Gonidec, Y., Rouillard, P., Mascle, J., Revel-Rolland, M., 2010. Lobe construction and sand/mud segregation by turbidity currents and debris flows on the western Nile deep-sea fan (Eastern Mediterranean). Sedimentary Geology 229, 124-143. https://doi.org/10.1016/j.sedgeo.2010.02.011

Millot, R., Guerrot, C., Vigier, N., 2004. Accurate and high-precision measurement of lithium isotopes in two reference materials by MC-ICP-MS. Geostandards and Geoanalytical Research 28, 153-159. https://doi.org/10.1111/j.1751-908X.2004.tb01052.x 
Misra, S., Froelich, P.N., 2012. Lithium Isotope History of Cenozoic Seawater: Changes in Silicate Weathering and Reverse Weathering. Science 335, 818-823. https://doi.org/10.1126/science.1214697

Mohtadi, M., Prange, M., Steinke, S., 2016. Palaeoclimatic insights into forcing and response of monsoon rainfall. Nature 533, 191-199. https://doi.org/10.1038/nature17450

Molliex, S., Kettner, A.J., Laurent, D., Droz, L., Marsset, T., Laraque, A., Rabineau, M., Moukandi N'Kaya, G.D., 2019. Simulating sediment supply from the Congo watershed over the last 155 ka Simulating sediment supply from the Congo watershed over the last $155 \mathrm{ka}$. Keywords. Quaternary Science Reviews 203, 38-55. https://doi.org/10.1016/j.quascirev.2018.11.001

Mologni, C., Revel, M., Blanchet, C., Bosch, D., Develle, A.-L., Orange, F., Bastian, L., Khalidi, L., Ducassou, E., Migeon, S., 2020. Frequency of exceptional Nile flood events as an indicator of Holocene hydro-climatic changes in the Ethiopian Highlands. Quaternary Science Reviews 247, 106543. https://doi.org/10.1016/j.quascirev.2020.106543

Nicholson, S.E., 2000. The nature of rainfall variability over Africa on times scales of decades to millennia. Global and Planetary Change 26, 137-158.

Padoan, M., Garzanti, E., Harlavan, Y., Villa, I.M., 2011. Tracing Nile sediment sources by Sr and Nd isotope signatures (Uganda, Ethiopia, Sudan). Geochimica et Cosmochimica Acta 75, 36273644. https://doi.org/10.1016/j.gca.2011.03.042

Palchan, D., Stein, M., Almogi-Labin, A., Erel, Y., Goldstein, S.L., 2013. Dust transport and synoptic conditions over the Sahara-Arabia deserts during the MIS6/5 and 2/1 transitions from grainsize, chemical and isotopic properties of Red Sea cores. Earth and Planetary Science Letters 382, 125-139. https://doi.org/10.1016/j.epsl.2013.09.013

Pistiner, J.S., Henderson, G.M., 2003. Lithium-isotope fractionation during continental weathering processes. Earth and Planetary Science Letters 214, 327-339. https://doi.org/10.1016/S0012$821 \times(03) 00348-0$

Pogge von Strandmann, Philip A.E., Vaks, A., Bar-Matthews, M., Ayalon, A., Jacob, E., Henderson, G.M., 2017. Lithium isotopes in speleothems: Temperature-controlled variation in silicate weathering during glacial cycles. Earth and Planetary Science Letters 469, 64-74. https://doi.org/10.1016/j.epsl.2017.04.014

Pogge von Strandmann, Philip A. E., Vaks, A., Bar-Matthews, M., Ayalon, A., Jacob, E., Henderson, G.M., 2017. Lithium isotopes in speleothems: Temperature-controlled variation in silicate weathering during glacial cycles. Earth and Planetary Science Letters 469, 64-74. https://doi.org/10.1016/j.epsl.2017.04.014

Pogge von Strandmann, P.A.E.P., Burton, K.W., James, R.H., van Calsteren, P., Gislason, S.R., 2010. Assessing the role of climate on uranium and lithium isotope behaviour in rivers draining a basaltic terrain. Chemical Geology 270, 227-239. https://doi.org/10.1016/j.chemgeo.2009.12.002

Pogge von Strandmann, P.A.E.P. von, Kasemann, S.A., Wimpenny, J.B., 2020. Lithium and Lithium Isotopes in Earth's Surface Cycles. Elements 16, 253-258. https://doi.org/10.2138/gselements.16.4.253

Reimer, P.J., Edouard Bard, B., Alex Bayliss, B., Warren Beck, B.J., Paul Blackwell, B.G., Christopher Bronk Ramsey, B., 2013. Intcal13 and Marine13 Radiocarbon Age Calibration Curves 050,000 Years Cal Bp. Radiocarbon 55, 1869-1887.

Revel, M., Colin, C., Bernasconi, S., Combourieu-Nebout, N., Ducassou, E., Grousset, F.E., Rolland, Y., Migeon, S., Bosch, D., Brunet, P., Zhao, Y., Mascle, J., 2014. 21,000 Years of Ethiopian African monsoon variability recorded in sediments of the western Nile deep-sea fan. Regional Environmental Change 14, 1685-1696. https://doi.org/10.1007/s10113-014-0588-x

Revel, M., Ducassou, E., Grousset, F.E., Bernasconi, S.M., Migeon, S., Revillon, S., Mascle, J., Murat, A., Zaragosi, S., Bosch, D., 2010. 100,000 Years of African monsoon variability recorded in sediments of the Nile margin. Quaternary Science Reviews 29, 1342-1362. https://doi.org/10.1016/j.quascirev.2010.02.006 
Revel, M., Ducassou, E., Skonieczny, C., Colin, C., Bastian, L., Bosch, D., Migeon, S., Mascle, J., 2015. 20,000 years of Nile River dynamics and environmental changes in the Nile catchment area as inferred from Nile upper continental slope sediments. Quaternary Science Reviews 130. https://doi.org/10.1016/j.quascirev.2015.10.030

Roberts, N., Taieb, M., Barker, P., Damnati, B., Icole, M., Williamson, D., 1993. Timing of the Younger Dryas event in East Africa from lake-level changes. Nature 366, 146-148. https://doi.org/10.1038/366146a0

Rohling, E.J., 1994. Review and new aspects concerning the formation of eastern Mediterranean sapropel. Marine Geochemistry 122, 1-28.

Rohling, E.J., Marino, G., Grant, K.M., 2015. Mediterranean climate and oceanography, and the periodic development of anoxic events (sapropels). Earth-Science Reviews 143, 62-97. https://doi.org/10.1016/j.earscirev.2015.01.008

Rossignol-Strick, M., Nesteroff, W., Olive, P., Vergnaud-grazzini, C., 1982. After the deluge: Mediterraean stagnation and sapropel formation. Nature 295.

Sanchez Goñi, M.F., Harrison, S.P., 2010. Millennial-scale climate variability and vegetation changes during the Last Glacial: Concepts and terminology. Quaternary Science Reviews 29, 28232827. https://doi.org/10.1016/j.quascirev.2009.11.014

Schefuß, E., Schouten, S., Schneider, R.R., 2005. Climatic controls on central African hydrology during the past 20,000 years. Nature 437, 1003-1006. https://doi.org/10.1038/nature03945

Scheuvens, D., Schütz, L., Kandler, K., Ebert, M., Weinbruch, S., 2013. Bulk composition of northern African dust and its source sediments - A compilation. Earth-Science Reviews 116, 170-194. https://doi.org/10.1016/j.earscirev.2012.08.005

Shanahan, T.M., Mckay, N.P., Hughen, K.A., Overpeck, J.T., Otto-Bliesner, B., Heil, C.W., King, J., Scholz, C.A., Peck, J., 2015. The time-transgressive termination of the African humid period. Nature Geoscience 8, 140-144. https://doi.org/10.1038/ngeo2329

Singarayer, J.S., Burrough, S.L., 2015. Interhemispheric dynamics of the African rainbelt during the late Quaternary. Quaternary Science Reviews 124, 48-67. https://doi.org/10.1016/j.quascirev.2015.06.021

Skonieczny, C., Mcgee, D., Winckler, G., Bory, A., Bradtmiller, L.I., Kinsley, C.W., 2019. Monsoondriven Saharan dust variability over the past 240,000 years. Science 5, 1-9.

Skonieczny, C., Paillou, P., Bory, A., Bayon, G., Biscara, L., Crosta, X., Eynaud, F., Malaizé, B., Revel, M., Aleman, N., Barusseau, J.P., Vernet, R., Lopez, S., Grousset, F., 2015. African humid periods triggered the reactivation of a large river system in Western Sahara. Nature Communications 6. https://doi.org/10.1038/ncomms9751

Snoeckx, H., Grousset, F., Revel, M., Boelaert, A., 1999. European contribution of ice-rafted sand to Heinrich layers H3 and H4. Marine Geology 158, 197-208. https://doi.org/10.1016/S00253227(98)00168-6

Stager, J.C., Johnson, T.C., 2008. The late Pleistocene desiccation of Lake Victoria and the origin of its endemic biota. Hydrobiologia 596, 5-16. https://doi.org/10.1007/s10750-007-9158-2

Talbot, M.R., Brendeland, K.I., 2001. Strontium Isotopes as Palaeohydrological Tracers in the White Nile Headwater Lakes, East Africa. AGU Fall Meeting Abstracts 21, PP21C-05.

Talbot, M.R., Lærdal, T., 2000. The Late Pleistocene - Holocene palaeolimnology of Lake Victoria, East Africa, based upon elemental and isotopic analyses of sedimentary organic matter. Journal of Paleolimnology 23, 141-164. https://doi.org/10.1023/A:1008029400463

Tanaka, T., Togashi, S., Kamioka, H., Amakawa, H., Kagami, H., Hamamoto, T., Yuhara, M., Orihashi, Y., Yoneda, S., Shimizu, H., Kunimaru, T., Takahashi, K., Yanagi, T., Nakano, T., Fujimaki, H., Shinjo, R., Asahara, Y., Tanimizu, M., Dragusanu, C., 2000. JNdi-1: A neodymium isotopic reference in consistency with LaJolla neodymium. Chemical Geology 168, 279-281. https://doi.org/10.1016/S0009-2541(00)00198-4

Tierney, J.E., DeMenocal, P.B., 2013. Abrupt Shifts in Horn of Africa Since the Last Glacial Maximum. Science 342, 843-846. https://doi.org/10.1126/science.1240411 
Tierney, J.E., Lewis, S.C., Cook, B.I., LeGrande, A.N., Schmidt, G.A., 2011a. Model, proxy and isotopic perspectives on the East African Humid Period. Earth and Planetary Science Letters 307, 103112. https://doi.org/10.1016/j.epsl.2011.04.038

Tierney, J.E., Pausata, F.S.R., De Menocal, P.B., 2017. Rainfall regimes of the Green Sahara. Science Advances 3, 1-10. https://doi.org/10.1126/sciadv.1601503

Tierney, J.E., Russell, J.M., Huang, Y., Sinninghe Damsté, J.S., Hopmans, E.C., Cohen, A.S., 2008. Northern hemisphere controls on tropical southeast African climate during the past 60,000 years. Science 322, 252-255. https://doi.org/10.1126/science.1160485

Tierney, J.E., Russell, J.M., Sinninghe Damsté, J.S., Huang, Y., Verschuren, D., 2011b. Late Quaternary behavior of the East African monsoon and the importance of the Congo Air Boundary. Quaternary Science Reviews 30, 798-807. https://doi.org/10.1016/j.quascirev.2011.01.017

Tierney, J.E., Smerdon, J.E., Anchukaitis, K.J., Seager, R., 2013. Multidecadal variability in East African hydroclimate controlled by the Indian Ocean. Nature 493, 389-392. https://doi.org/10.1038/nature11785

Tjallingii, R., Claussen, M., Stuut, J.-B.W., Fohlmeister, J., Jahn, A., Bickert, T., Lamy, F., Röhl, U., 2008. Coherent high- and low-latitude control of the northwest African hydrological balance. Nature Geosci 1, 670-675. https://doi.org/10.1038/ngeo289

Verschuren, D., Russell, J.M., 2009. Paleolimnology of African lakes : Beyond the exploration phase. PAGES news 17, 112-114. https://doi.org/10.1029/2008JD010145.Yancheva

Verschuren, D., Sinninghe Damsté, J.S., Moernaut, J., Kristen, I., Blaauw, M., Fagot, M., Haug, G.H., 2009. Half-precessional dynamics of monsoon rainfall near the East African Equator. Nature 462, 637-641. https://doi.org/10.1038/nature08520

Vigier, N., Decarreau, A., Millot, R., Carignan, J., Petit, S., France-Lanord, C., 2008. Quantifying Li isotope fractionation during smectite formation and implications for the Li cycle. Geochimica et Cosmochimica Acta 72, 780-792. https://doi.org/10.1016/j.gca.2007.11.011

Vigier, N., Gislason, S.R., Burton, K.W., Millot, R., Mokadem, F., 2009. The relationship between riverine lithium isotope composition and silicate weathering rates in Iceland. Earth and Planetary Science Letters 287, 434-441. https://doi.org/10.1016/j.epsl.2009.08.026

Viste, E., Sorteberg, A., 2013. The effect of moisture transport variability on Ethiopian summer precipitation. International Journal of Climatology 33, 3106-3123. https://doi.org/10.1002/joc.3566

Waelbroeck, C., Pichat, S., Böhm, E., Lougheed, B.C., Faranda, D., Vrac, M., Missiaen, L., Vazquez Riveiros, N., Burckel, P., Lippold, J., Arz, H.W., Dokken, T., Thil, F., Dapoigny, A., 2018. Relative timing of precipitation and ocean circulation changes in the western equatorial Atlantic over the last 45\&thinsp;kyr. Clim. Past 14, 1315-1330. https://doi.org/10.5194/cp-14-1315-2018

Wang, Y., Cheng, H., Edwards, R.L., Kong, X., Shao, X., Chen, S., Wu, J., Jiang, X., Wang, X., An, Z., 2008. Millennial- and orbital-scale changes in the East Asian monsoon over the past 224,000 years. Nature 451, 1090-1093. https://doi.org/10.1038/nature06692

Weldeab, S., Emeis, K.C., Hemleben, C., Schmiedl, G., Schulz, H., 2003. Spatial productivity variations during formation of sapropels S5 and S6 in the Mediterranean Sea: Evidence from Ba contents. Palaeogeography, Palaeoclimatology, Palaeoecology 191, 169-190. https://doi.org/10.1016/S0031-0182(02)00711-3

Weldeab, S., Menke, V., Schmiedl, G., 2014. The pace of East African monsson evolution during the Holocene. Geophysical Research Letters 41, 1724-1731. https://doi.org/10.1002/2014GL059361.Received

Williams, M., 2019. The Nile Basin: Quaternary Geology, Geomorphology and Prehistoric Environments, 1st ed. Cambridge University Press. https://doi.org/10.1017/9781316831885

Williams, M., Talbot, M., Aharon, P., Abdl Salaam, Y., Williams, F., Inge Brendeland, K., 2006. Abrupt return of the summer monsoon 15,000 years ago: new supporting evidence from the lower White Nile valley and Lake Albert. Quaternary Science Reviews 25, 2651-2665. https://doi.org/10.1016/j.quascirev.2005.07.019 
Williams, M.A.J., Usai, D., Salvatori, S., Williams, F.M., Zerboni, A., Maritan, L., Linseele, V., 2015. Late Quaternary environments and prehistoric occupation in the lower White Nile valley, central Sudan. Quaternary Science Reviews 130, 72-88. https://doi.org/10.1016/j.quascirev.2015.03.007

Williams, M.A.J., Williams, F.M., Duller, G.A.T., Munro, R.N., El Tom, O.A.M., Barrows, T.T., Macklin, M., Woodward, J., Talbot, M.R., Haberlah, D., 2010. Late Quaternary floods and droughts in the Nile valley, Sudan: new evidence from optically stimulated luminescence and AMS radiocarbon dating. Quaternary Science Reviews 29, 1116-1137. https://doi.org/10.1016/j.quascirev.2010.02.018

Wimpenny, J., Gíslason, S.R., James, R.H., Gannoun, A., Pogge Von Strandmann, P.A.E., Burton, K.W., 2010. The behaviour of $\mathrm{Li}$ and $\mathrm{Mg}$ isotopes during primary phase dissolution and secondary mineral formation in basalt. Geochimica et Cosmochimica Acta 74, 5259-5279. https://doi.org/10.1016/j.gca.2010.06.028

Woodward, J., Macklin, M., Fielding, L., Millar, I., Spencer, N., Welsby, D., Williams, M., 2015. Shifting sediment sources in the world's longest river: A strontium isotope record for the Holocene Nile. Quaternary Science Reviews 130, 124-140. https://doi.org/10.1016/j.quascirev.2015.10.040

Ziegler, M., Tuenter, E., Lourens, L.J., 2010. The precession phase of the boreal summer monsoon as viewed from the eastern Mediterranean (ODP Site 968). Quaternary Science Reviews 29, 1481-1490. https://doi.org/10.1016/j.quascirev.2010.03.011 


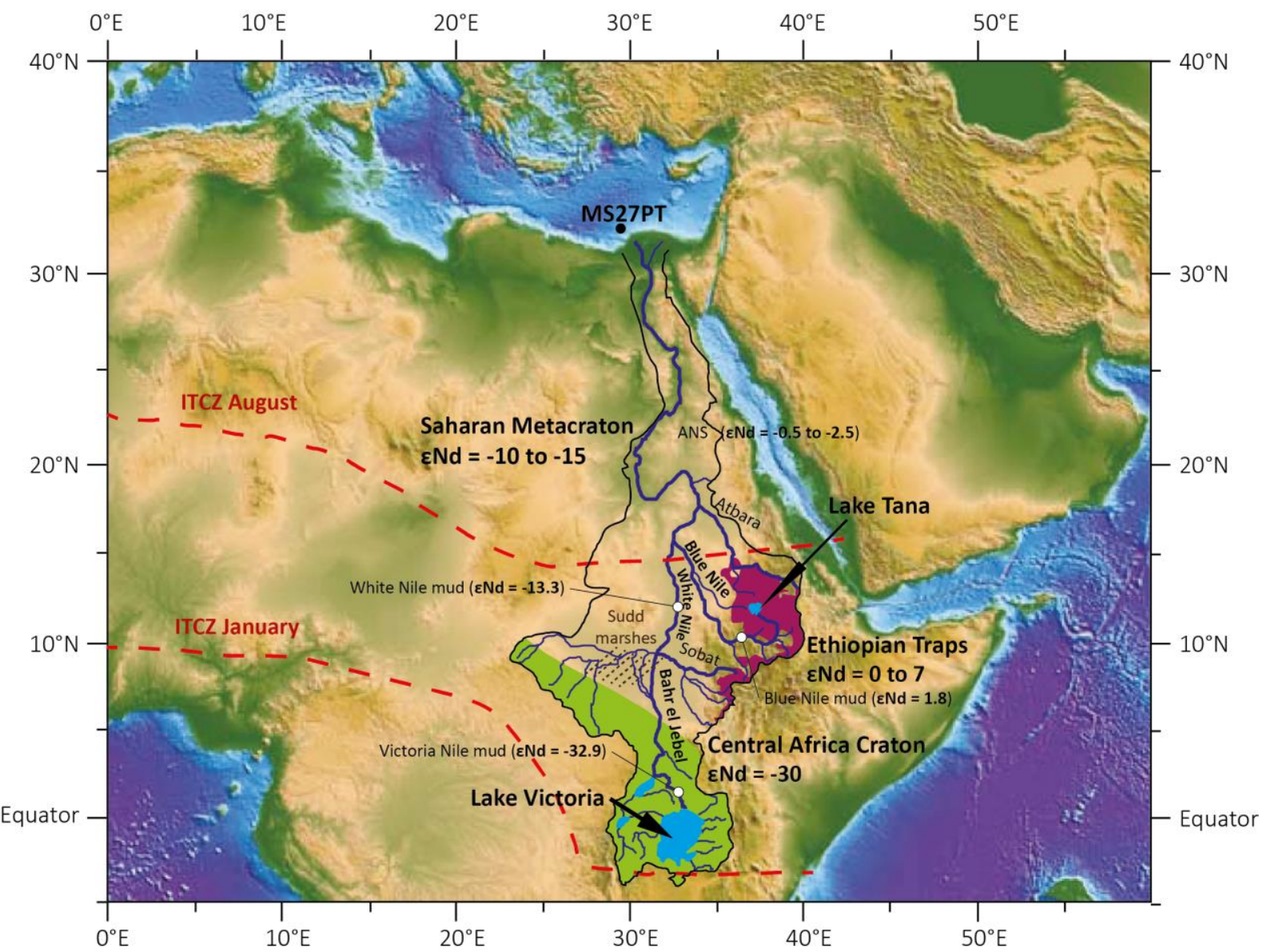

Figure 1 : Map of the Nile River basin and location of core MS27PT (N31 ${ }^{\circ} 47.90^{\prime} ;$ E29 $^{\circ} 27.70^{\prime}, 1389 \mathrm{~m}$ water deep). Three main sources of suspended sediment load are identified in the Nile basin: the basaltic rocks (purple) of the Ethiopian Traps (Highlands), which are drained by the Blue Nile, the Atbara and Sobat rivers located in tropical latitude (around 5 to $15^{\circ} \mathrm{N}$ ); The Precambrian metamorphic rocks (green) of the Central African Craton located in the equatorial latitude of the lakes Albert and Victoria in the Ugandan headwaters region of the White Nile, which are drained by the Bahr el Jebel River; and the Saharan Metacraton sources (Abdelsalam et al., 2002; Grousset and Biscaye, 2005; Scheuvens et al., 2013). ENd of the Victoria, While and Blue Nile River mud samples are 


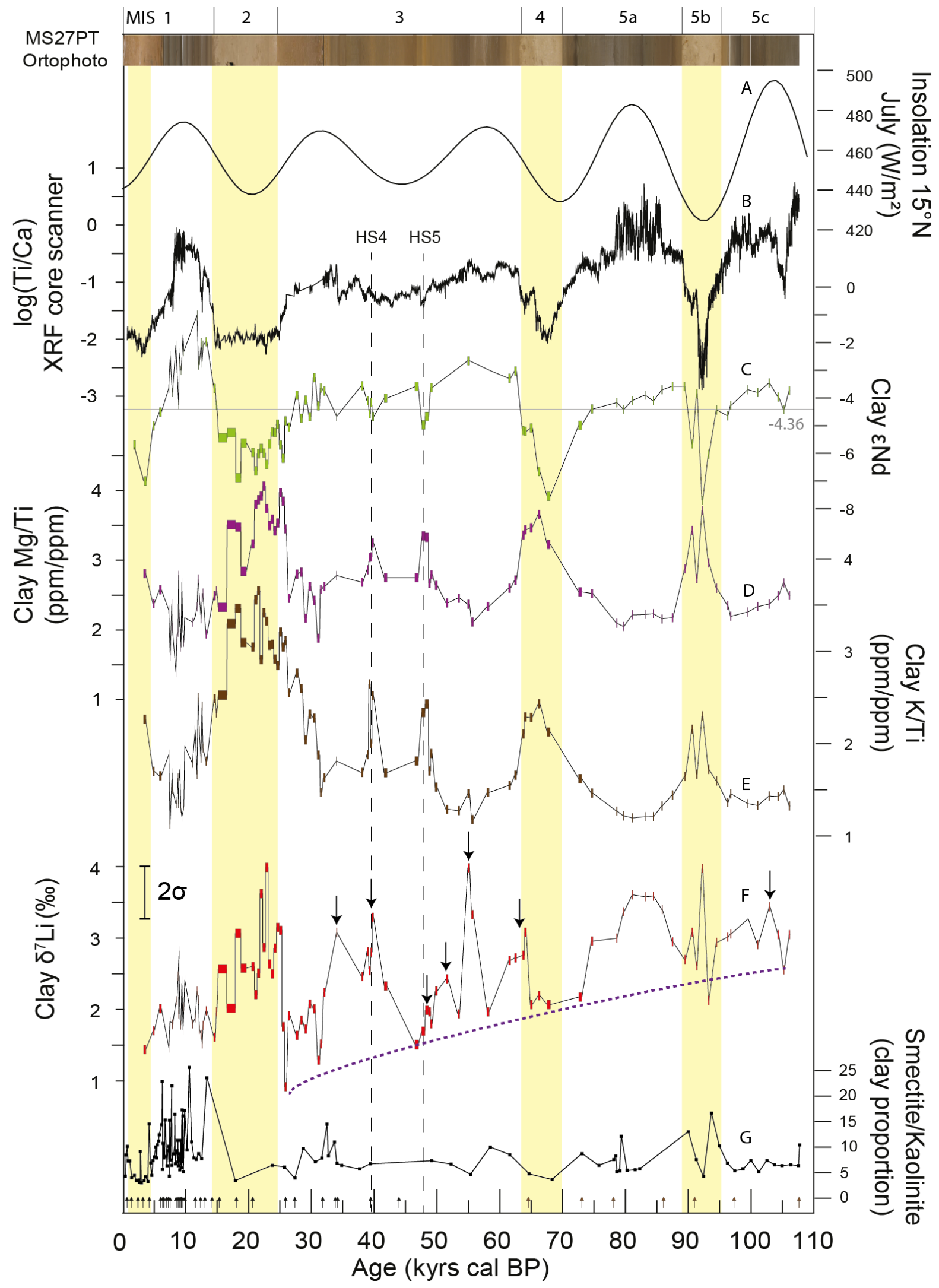

Figure 2 : Paleo-variations in (A) July insolation at $15^{\circ} \mathrm{N}$ (Berger and Loutre, 1991), (B) log(Ti/Ca) ratio in the MS27PT bulk fraction (Revel et al., 2010) , (C), (D), (E), (F) and (G) clay $\varepsilon N d, M g / T i$ ratio, K/Ti ratio, $\delta^{7} \mathrm{Li}$ and smectite/kaolinite ratio for the last $110 \mathrm{ka}$ (MIS: Marine Isotopic Stage). Grey line 
represent the average $\varepsilon N d$ value recorded over $110 \mathrm{ka}$. A photography of the MS27PT core is shown for comparison, with the humid and arid periods characterized by dark and light sediments respectively. The yellow bands correspond to the arid periods and dotted lines to Heinrich Stadials 4 and 5. Arrows show $\delta^{7} L i$ excursion during specific short-term periods. The progressive decrease of the $\delta^{7} \mathrm{Li}$ minima corresponds to dotted line. Black arrows refer to ${ }^{14} \mathrm{C}$ ages, brown arrows to age calibration from the $\delta^{18} \mathrm{O}$ of planktonic foraminifera.

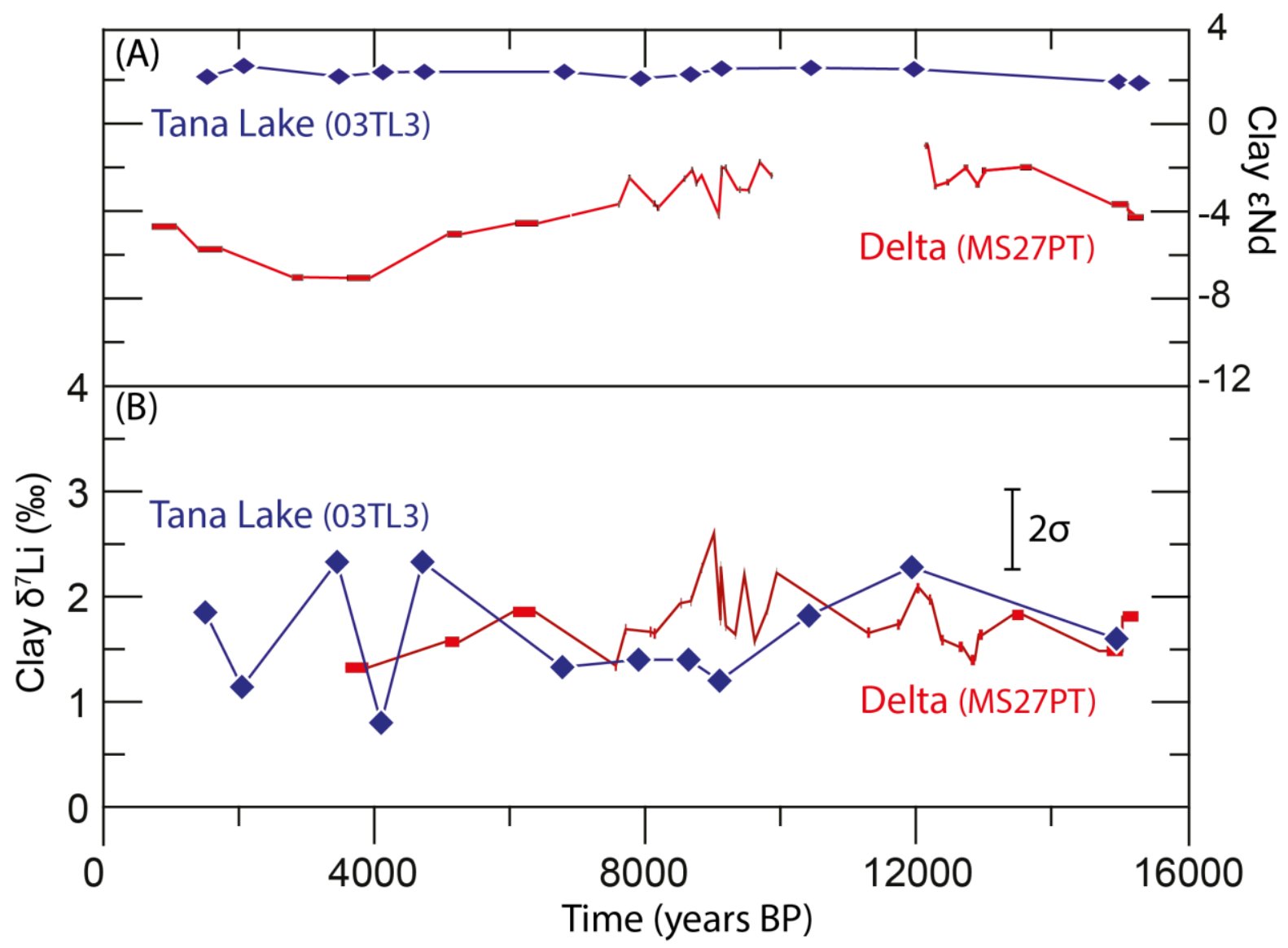

Figure 3 : Clay $\delta^{7} L i$ and $\varepsilon N d$ as a function of the sediment age in the Lake Tana in Ethiopia (blue; core 03TL3) and for MS27PT Nile delta core downstream (red). The 2SD of the ENd values range between 0.08 and 0.45 . 


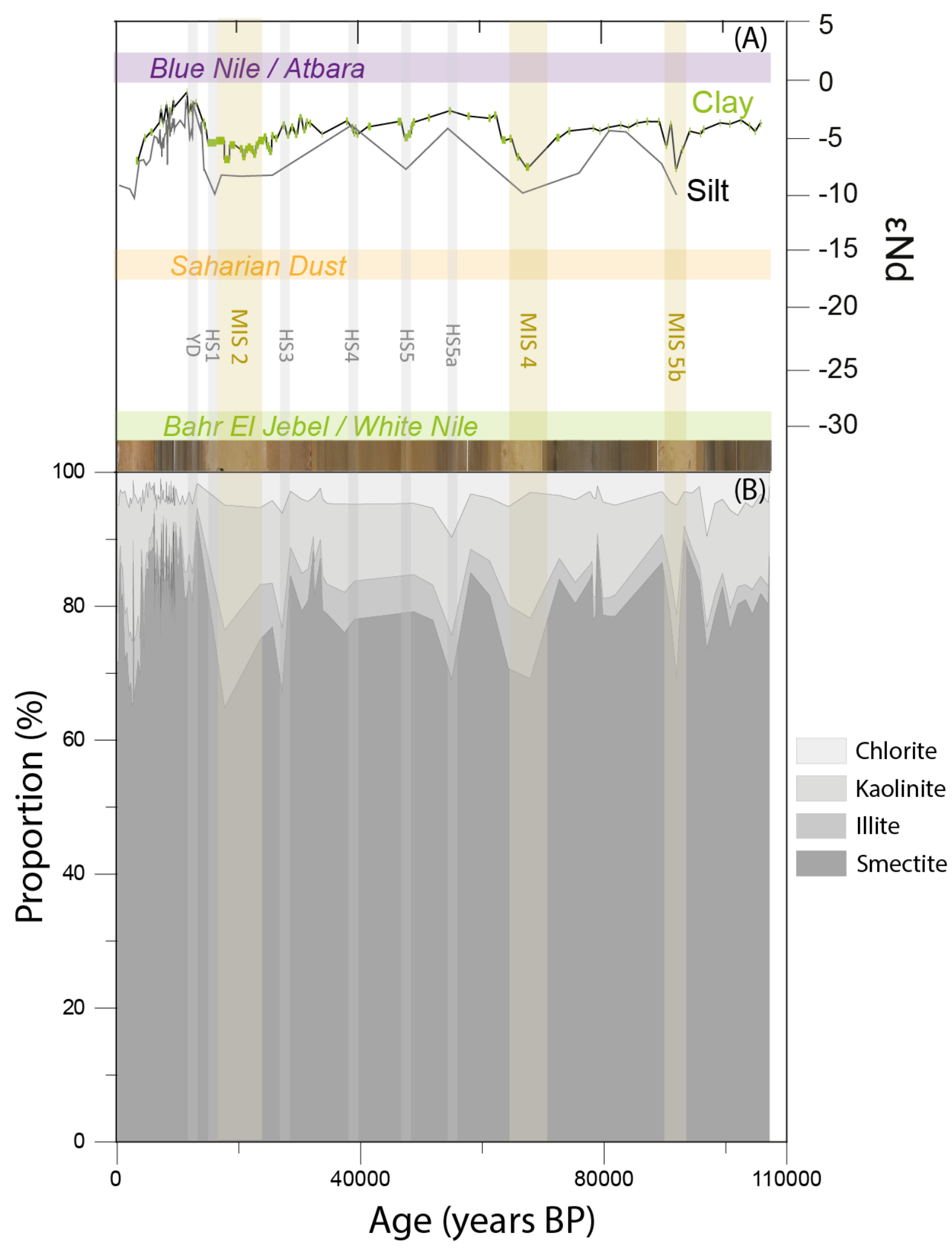

Figure 4 : (A) $\varepsilon N d$ values of clay fraction (green, Bastian et al., 2017) and of <63 $\mu m$ fraction (grey line; Revel et al., 2010, 2015) of MS27PT sediment. (B) Percentage of clay estimated by $X R D$ as a function of time. Light brown and grey bars indicate arid periods corresponding to MIS 2, 4, $5 b$ and to Heinrich Stadials and youger Dryas events. 


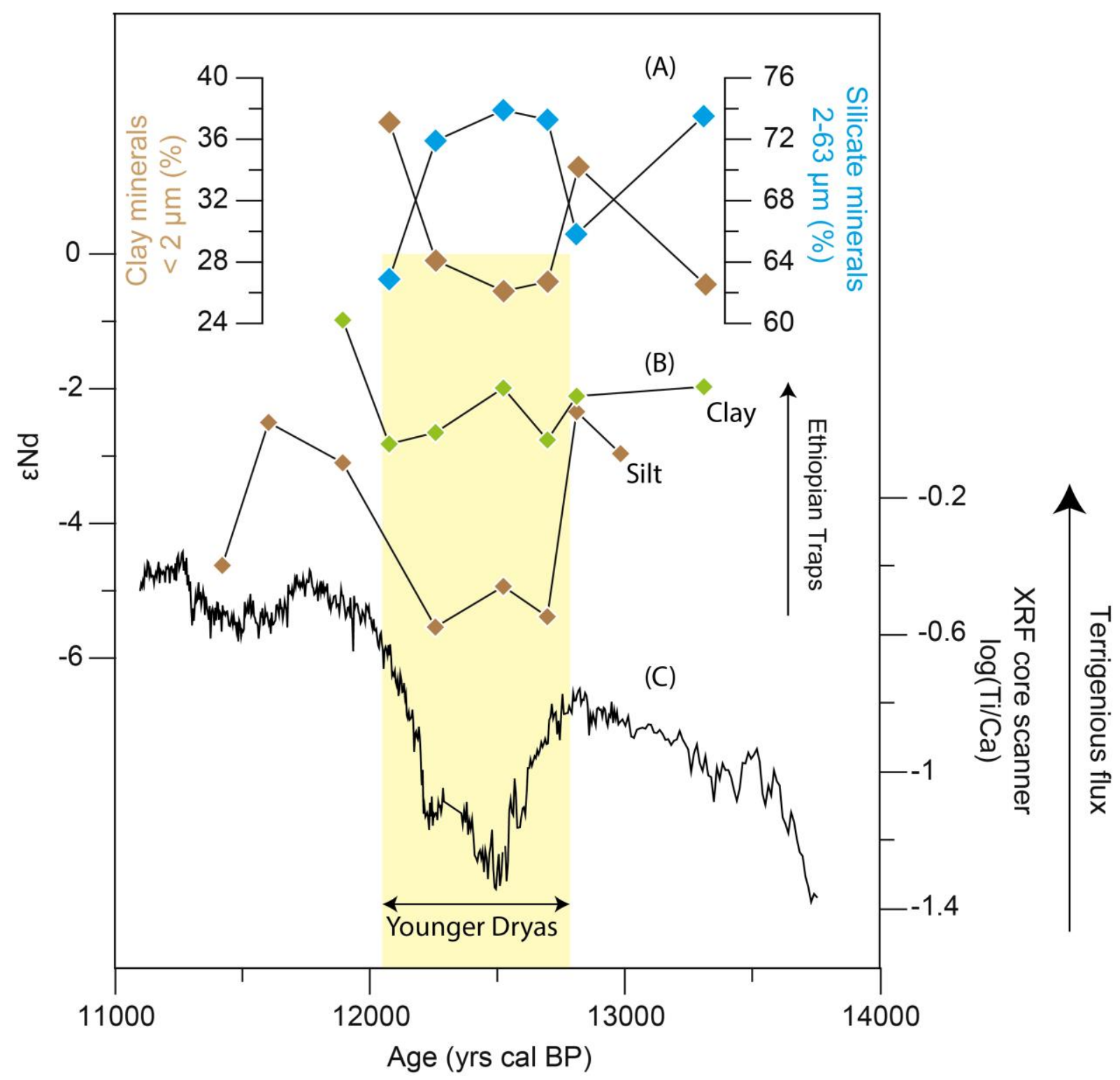

Figure 5: Paleo-variations between 11 and 14 kyrs in (A) measured minerals proportion (brown) and silicate minerals proportion (blue), (B), clay $\varepsilon N d$ (green) and $<63 \mu m$ fraction $\varepsilon N d$ (brown, (Revel et al., 2015)) (C) $\log (\mathrm{Ti} / \mathrm{Ca}$ ) measured by XRF core scanner (Revel et al., 2010). The 2SD of the $\varepsilon N d$ range between 0.08 and 0.45 . 


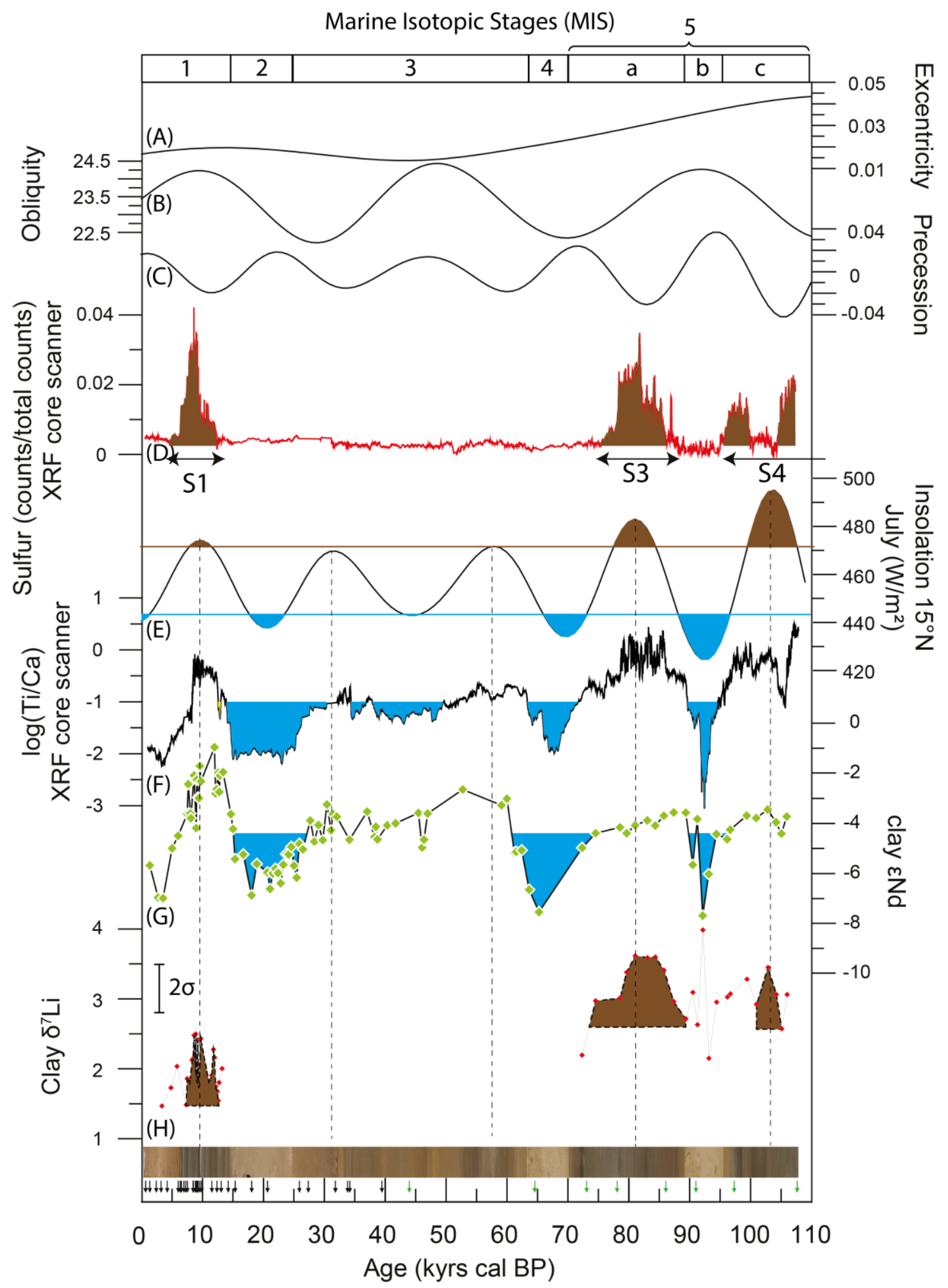

Figure 6 : Paleo-variations in (A) Eccentricity (B) Obliquity, (C) Precession, (D) Sulphur measured by XRF core scanner in core MS27PT (Revel et al., 2010), (E) insolation at $15^{\circ} \mathrm{N}$ in July $\left(\mathrm{W} / \mathrm{m}^{2}\right)$ (F) log(Ti/Ca) measured by XRF core scanner in MS27PT sediment (Revel et al., 2010) (G) and (H) clay $\varepsilon N d$ and $\delta^{7} L i$ in MS27PT sediment. The blue and brown patterns correspond respectively to the minimum and maximum insolation values for the last 110 kyrs. 

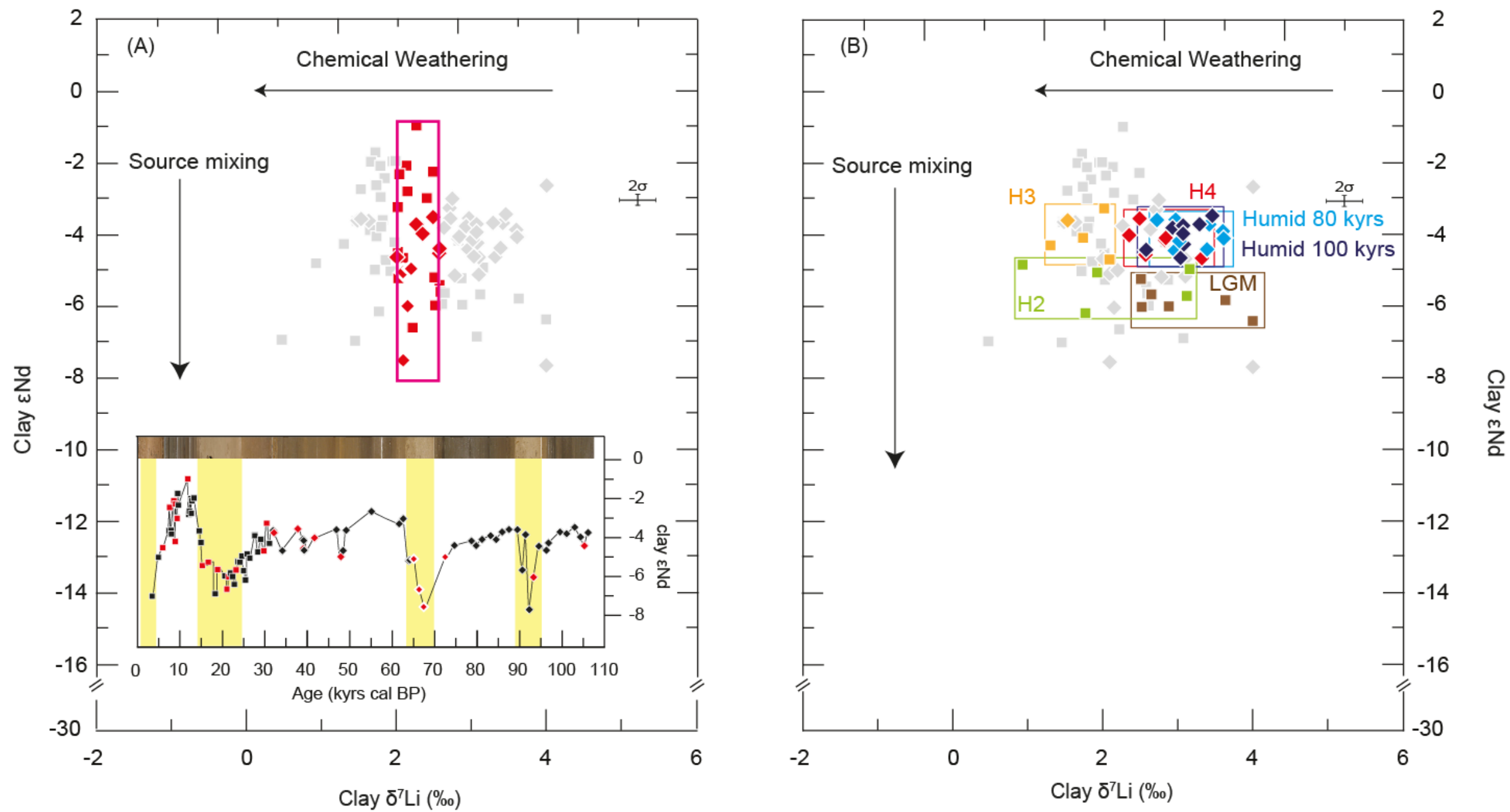

Figure 7 : Clay $\varepsilon N d$ as a function of $\delta^{7} L i$. (A) The red symbols represent samples with similar $\delta^{7} L i(\approx 2 \%)$ and variable $\varepsilon N d$. [B) Representation of different periods of time with constant clay $\varepsilon N d$. The squares and the diamonds correspond respectively to the samples of Bastian et al., (2017) and of this study. 


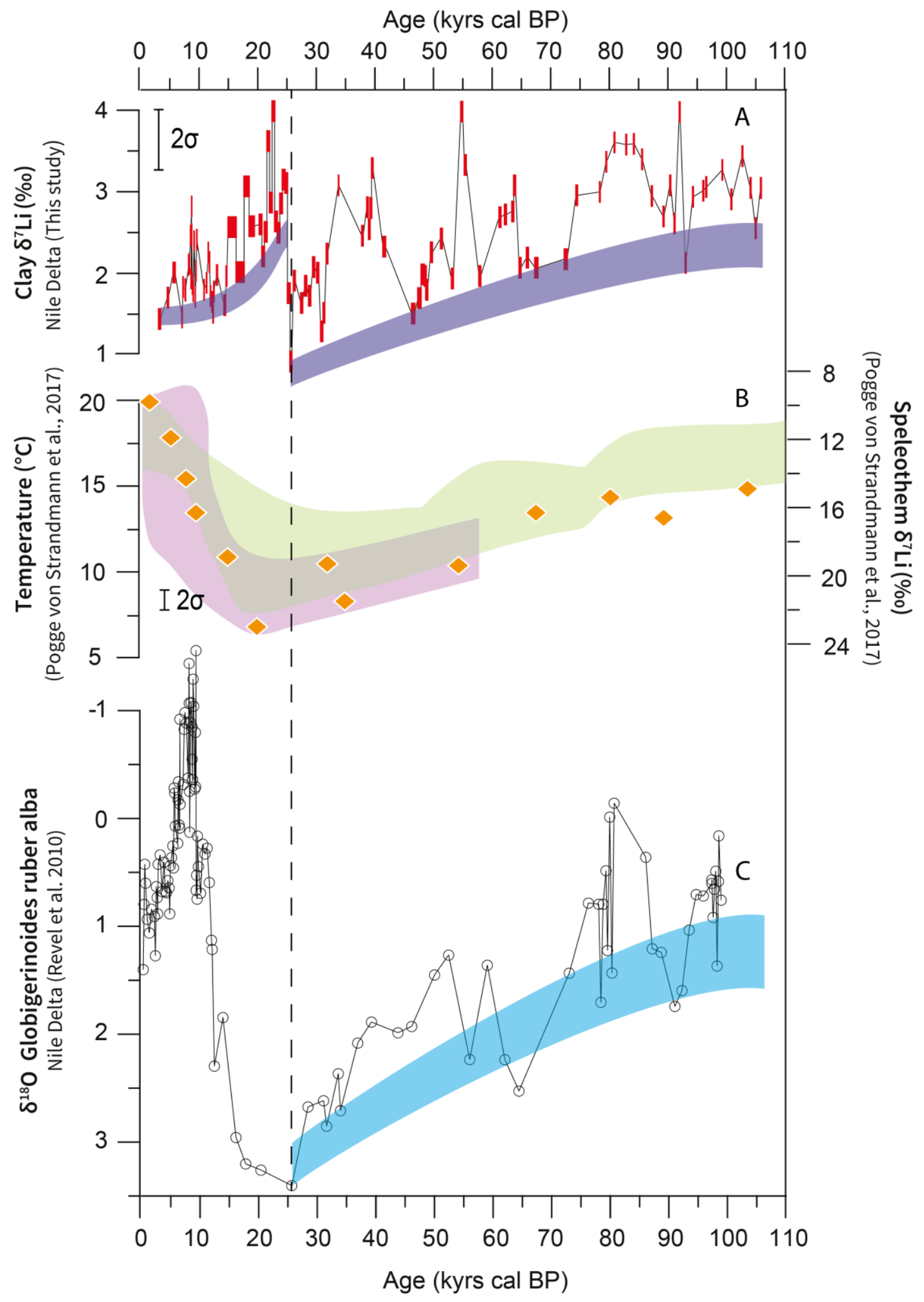

Figure 8: Paleovariation of (A) clay $\delta^{7} \mathrm{Li}$ in core MS27PT, (B) $\delta^{7} \mathrm{Li}$ in Speleothem from Soreq cave (Israel). The green and violet bands correspond to the temperature reconstruction respectively with hydrogen isotopes and clumped isotopes (Pogge von Strandmann et al., 2017); (C) Globigerinoides ruber alba $\delta^{18} \mathrm{O}$ in core MS27PT (Revel et al., 2010 \& 2015). 


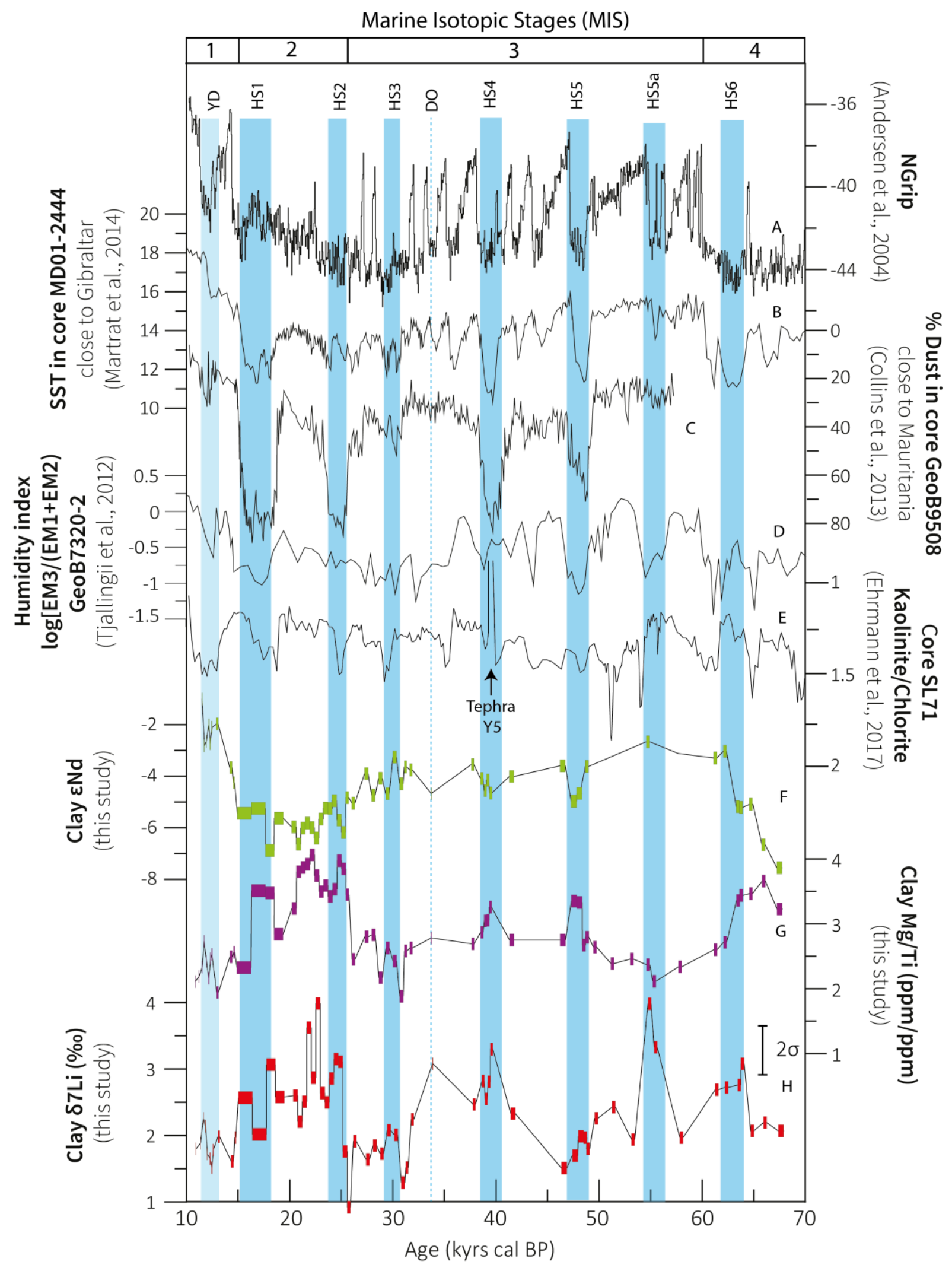

Figure 9: Paleovariations in (A) NGrip $\delta^{18} O$ (Andersen et al., 2004), (B) Reconstructed Sea Surface Temperature (SST, $\left.{ }^{\circ} \mathrm{C}\right)$ for North Atlantic (Martrat et al., 2014), (C) Estimation of Dust in core GeoB9508 close to Gibraltar (Collins et al., 2013), (D) Estimation of Humidity index of central Africa from the core GeoB7320-2 (Tjallingii et al., 2008), (E) Kaolinite/Chlorite ratio from SL71 core 
1231 (Ehrmann et al., 2017), (F), (G) and (H) clay Mg/Ti ratio, clay K/Ti ratios and clay $\delta^{7}$ Li. The blue band 1232 represents the Heinrich Stadial (HS) and the Younger Dryas (YD). 


\section{Co-variations of climate and silicate weathering in the Nile Basin during the Late Pleistocene}

$*^{\mathrm{co}}-1^{\mathrm{st}}$ authors

1245

†corresponding author: mologni@geoazur.unice.fr

1246

${ }^{1}$ Université de la Cote d'Azur, CNRS, OCA, IRD, Geoazur, 250 rue Albert Einstein, 06500 Valbonne, France

${ }^{2}$ Laboratoire d'Océanographie de Villefranche sur Mer (LOV, IMEV), CNRS, Sorbonne Université, 181 chemin du Lazaret, 06320, Villefranche sur Mer, France

${ }^{3}$ IFREMER, Unité de Recherche Géosciences Marines, 29280 Plouzané, France

${ }^{4}$ Department of Geography and Earth Sciences, Aberystwyth University, Aberystwyth SY23 $3 \mathrm{DB}, \mathrm{UK}$

5 Géosciences Montpellier, UMR-CNRS 5243, Université de Montpellier , 34095 Montpellier, France 
1263 Core MS27PT is $7.3 \mathrm{~m}$ long and cover $110 \mathrm{kyr}$. The age model for core MS27PT is based on 126429 AMS ${ }^{14} \mathrm{C}$ dates first published in (Bastian et al., 2017; Revel et al., 2015, 2010). These ${ }^{14} \mathrm{C}$ 1265 dates were calibrated using the Calib 7.0 program (Reimer et al., 2013) and a mean marine 1266 reservoir age of 400 years. For the period extending from 110 to $46 \mathrm{kyr} \mathrm{BP}$, the age model is 1267 taken from Revel et al., (2010) and is based on the age of the sapropel S3 (86 to 78 kys BP) 1268 and the sapropel S4 ( S4b: $108 \mathrm{kyr}$ BP, S4a: $102 \mathrm{kyrs}$ BP). Additionally, the oxygen isotope 1269 record of MS27PT is correlated with the isotope record of the SPECMAP reference timescale 1270 for the Marine Isotope Stage 4 and 5 (Cornuault et al., 2016; Kallel et al., 2000; Revel et al., 1271 2010).

1272 The change in marine/terrigenous material and within the detrital material have been 1273 investigated by comparing the $\mathrm{Ti} / \mathrm{Ca}$ and $\mathrm{Ti} / \mathrm{K}$ ratios. The enrichment in $\mathrm{Ti}$ for humid periods 1274 indicate a higher contribution by Nile flood particles. The enrichment in $\mathrm{K}$ for arid periods 1275 and for some of the heinrich events most probably indicates a change in source and also a 1276 change in weathering of suspended matter.For some specific climate episodes such as the 1277 Heinrich events, we have based our sampling on K/Ti ratio variations. 


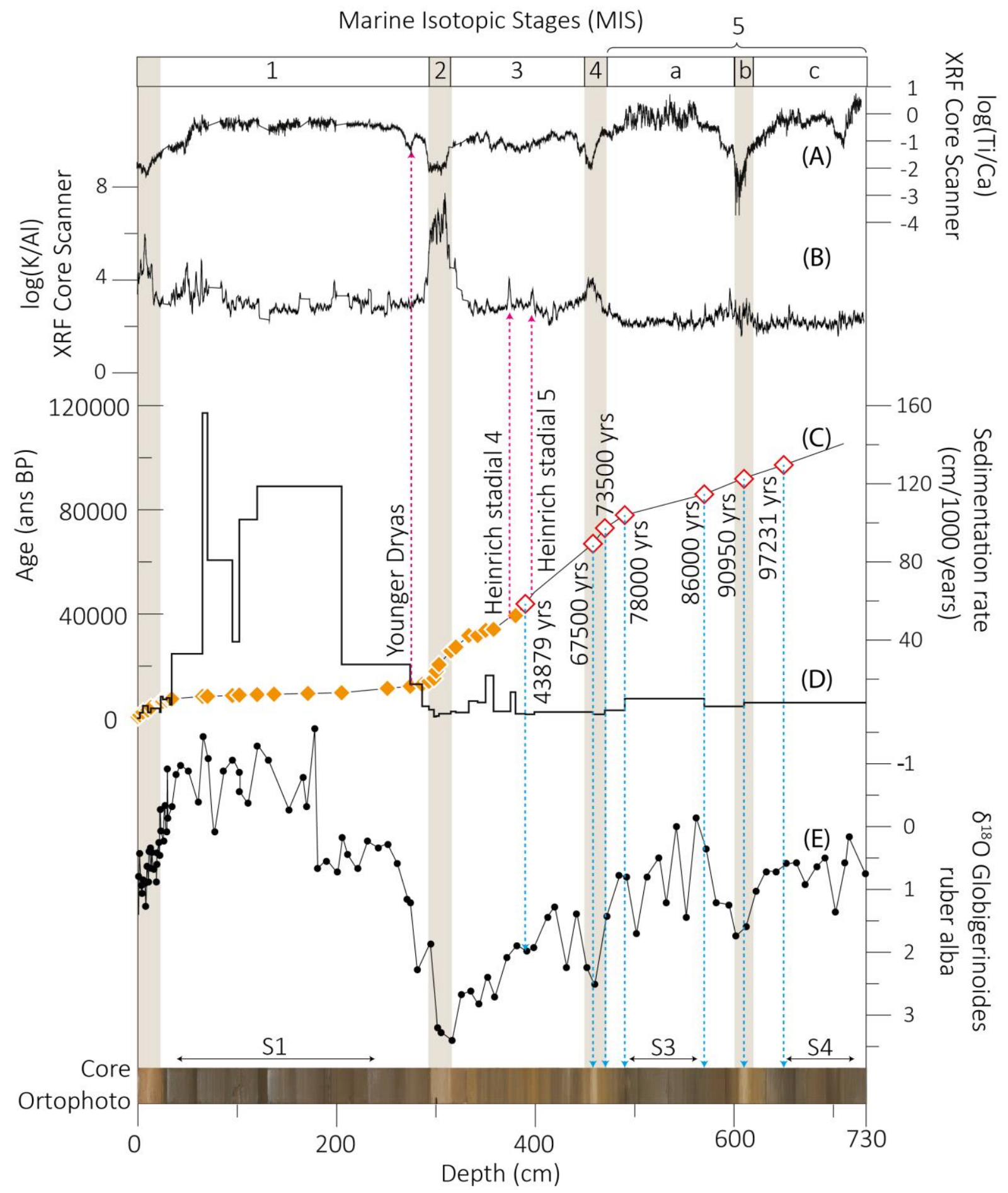

Figure S1 :). (A) $\log (\mathrm{Ti} / \mathrm{Ca}$ ) determined by XRF core scanner (Revel et al., 2010). (B) K/Al determined by XRF core scanner (Revel et al., 2010 (C) AMS 14C ages in orange, calibrated age in red (D) Sedimentation rate ( $\mathrm{mm} / 1000$ years). (E) $\delta^{18} \mathrm{O}$ of Globigerinoides ruber alba (Revel et al., 2010). The blue arrows indicate the age calibration after 45000 years and purple arrows indicate the Heinrich stadial 4 and 5 and Younger Dryas. 

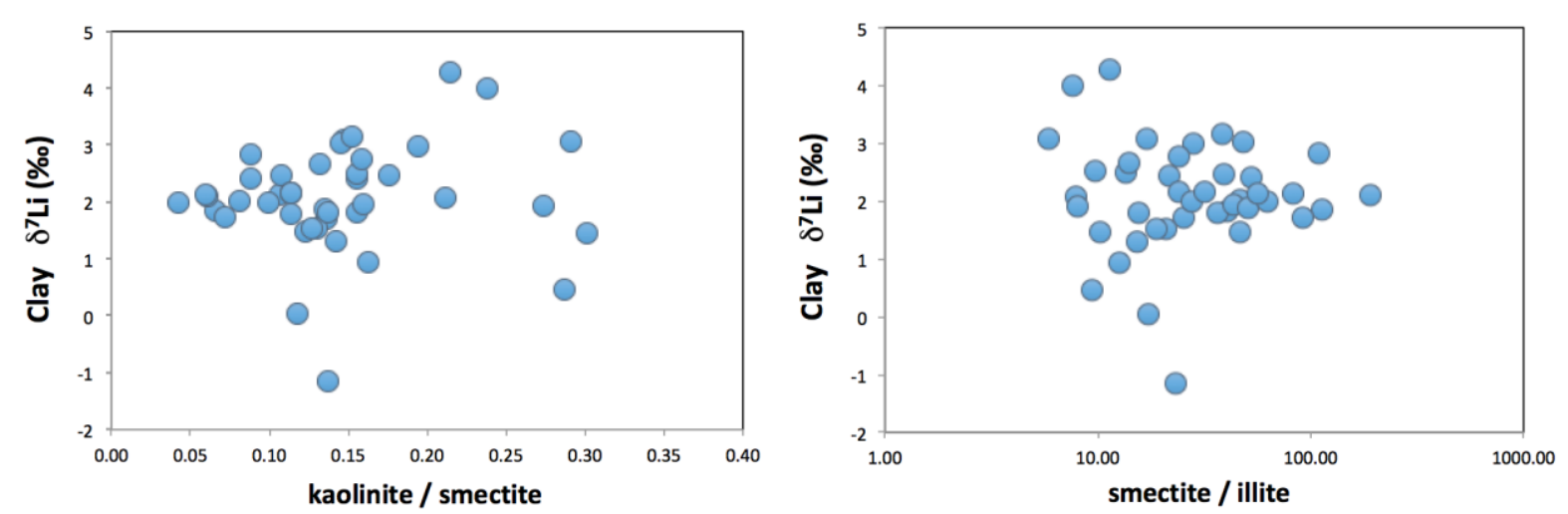

Figure S2: Clay $\delta^{7} \mathrm{Li}$ as a function of kaolinite/smectite ratio and smectite /illite ratio. There is no apparent correlation between clay mineralogy and clay Li isotope composition over the last 100kyrs, mostly because smectite remained the dominant phase $(>70 \%)$, and likely also because of similar isotope fractionation during Li uptake by these various phases.

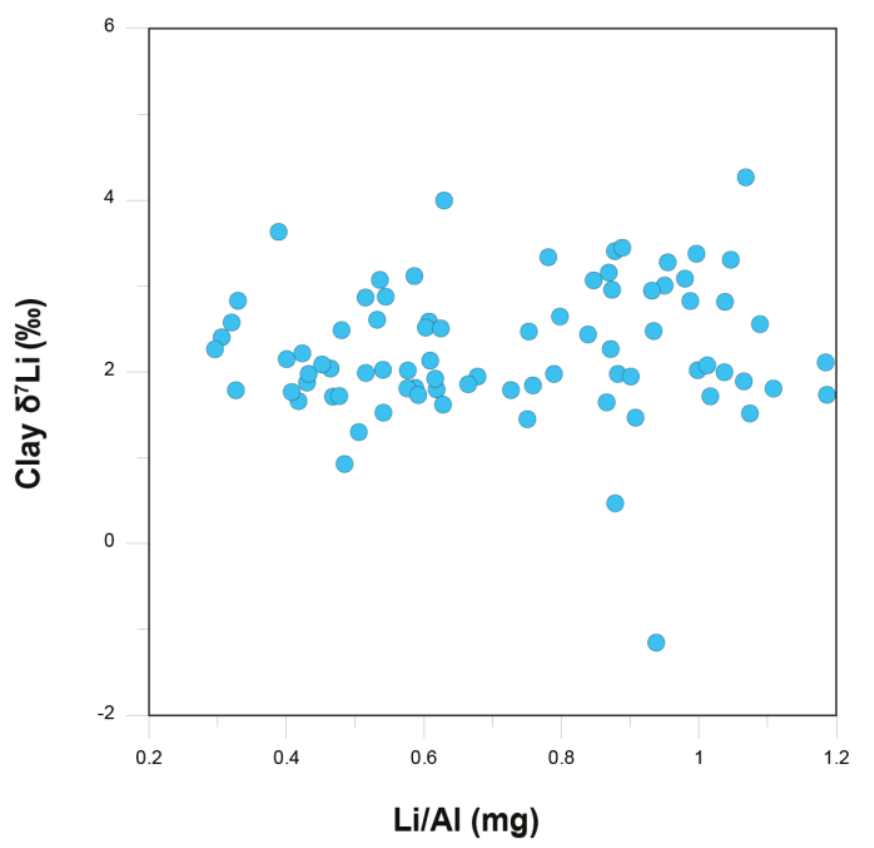

Li/Al (mg)

Figure S3 : Clay $\delta^{7} \mathrm{Li}$ as a function of their Li/Al ratio, evidencing the lack of control by mineral mixing or by significant contribution from high Li/Al - low $\delta$ Li shales (see Dellinger et al. 2017). 